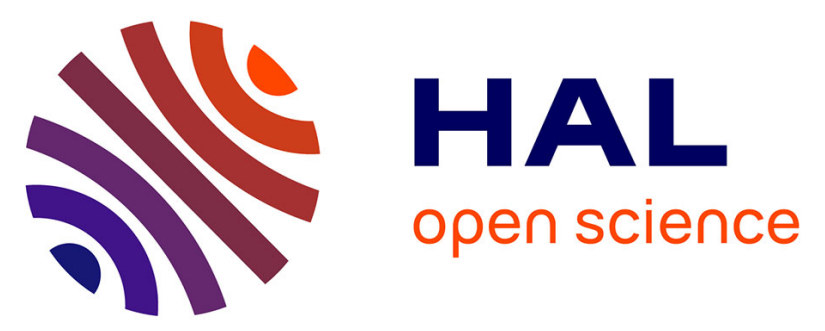

\title{
Recycling biosolids and lake-dredged materials to pasture-based animal agriculture: alternative nutrient sources for forage productivity and sustainability. A review
}

Gilbert C. Sigua

\section{To cite this version:}

Gilbert C. Sigua. Recycling biosolids and lake-dredged materials to pasture-based animal agriculture: alternative nutrient sources for forage productivity and sustainability. A review. Agronomy for Sustainable Development, 2009, 29 (1), pp.143-160. hal-00886477

\section{HAL Id: hal-00886477 https://hal.science/hal-00886477}

Submitted on 1 Jan 2009

HAL is a multi-disciplinary open access archive for the deposit and dissemination of scientific research documents, whether they are published or not. The documents may come from teaching and research institutions in France or abroad, or from public or private research centers.
L'archive ouverte pluridisciplinaire HAL, est destinée au dépôt et à la diffusion de documents scientifiques de niveau recherche, publiés ou non, émanant des établissements d'enseignement et de recherche français ou étrangers, des laboratoires publics ou privés. 


\title{
Recycling biosolids and lake-dredged materials to pasture-based animal agriculture: alternative nutrient sources for forage productivity and sustainability. A review
}

\author{
Gilbert C. SIGUA* \\ Research Soil Scientist, United States Department of Agriculture-Agricultural Research Service Subtropical Agricultural Research Station, Brooksville, \\ FL 34601, USA
}

(Accepted 18 June 2008)

\begin{abstract}
Domestic sewage sludge or biosolids and lake-dredged materials are examples of materials that can be used to cut fertilizer costs in pasture-based animal agriculture. Sustainable biosolids and lake-dredged materials management is based upon controlling and influencing the quantity, quality and characteristics of these materials in such a way that negative impacts to the environment are avoided and beneficial uses are optimized. This article examines the following two key questions. Is the use of these materials in an agricultural setting harmless and sensible? Is the use of biosolids secure in all climates, in all soils and is it sustainable over the long term? Recycling biosolids and lake-dredged materials to pasture-based animal production is quite productive as alternative nutrient sources for forage production. Perennial grass can be a good choice for repeated applications of biosolids and lake-dredged materials. Although biosolids and lake-dredged materials supply some essential plant nutrients and provide soil property-enhancing organic matter, land-application programs still generate some concerns because of possible health and environmental risks involved. Repeated applications of biosolids and lake-dredged materials indicate no harmful effects on soil quality and forage quality. Beneficial uses of biosolids and lake-dredged materials are both economical and environmental. The concentrations of soil nitrogen and phosphorus following repeated application of biosolids were far below the contamination risk in the environment. The residual effect of biosolids over the long term can be especially significant in many forage-based pastures where only $50 \%$ of the million hectares of pastures are given inorganic nitrogen yearly. Long-term studies have demonstrated the favorable and beneficial effects of added lake-dredged materials on the early establishment of bahiagrass in sandy pasture fields. Often these materials can be obtained at little or no cost to the farmers or landowners. Lake-dredged materials can be used as soil amendments (lime and fertilizer) for early establishment of bahiagrass in beef cattle pastures. Bahiagrass in plots that were treated with biosolids and lake-dredge materials had significantly higher forage yield and crude protein content when compared with those bahiagrass in the control plots or untreated plants.
\end{abstract}

sewage sludge / carry-over effect / bahiagrass / forage productivity / ecological implication / domestic wastewater / beef cattle / subtropical pastures / lake-dredged materials / forage-based pasture / agriculture / environment / biosolids / dredging

\section{INTRODUCTION}

Wastewater treatment in the United States represents a major effort to keep the nation's waters clean. Sewage sludge is the solid, semisolid, or liquid residue generated during treatments of domestic sewage. Although biosolids supply some essential plant nutrients and impart soil property enhancing organic matter, land application programs still generated apprehension because of possible health and environmental risks involved (Berti and Jacobs, 1996; Alloway and Jackson, 1991). Repeated biosolids applications are feasible in an intensive forage system, but field managers will need to adjust rates or cease applications as appropriate to avoid excess nitrogen or phosphorus concentrations in soil which may lead to undesir-

* Corresponding author: gilbert.sigua@ars.usda.gov able accumulations of these nutrients, potential for harming the environment (Sigua et al., 2005; Adjei and Rechcigl, 2002; Cogger et al., 2001; Zebarth et al., 2000; Cogger et al., 1999; Sullivan, 1998; Sullivan et al., 1997; Fresquez et al., 1990). There are also wide public health trepidation of soil contamination with trace metals and pathogens from repeated application of biosolids. Pathogens tend to persist in less than a year, but trace or even heavy metals associated with biosolids may tend to persevere in the environment for much longer period (Henry et al., 1994; Cavallaro et al., 1993).

The continued need to dredge ports, waterways, lakes, rivers, and canal both for maintenance and environmental improvement will produce millions of cubic meters of lake-dredged materials. These bottom sediment materials are composed of upland soil enriched with nutritive organics, trace metals and contaminants. Productive disposal options of these 
materials may provide substantial and vital benefits that will enhance the environment, community and society. Dredged or spoil materials because of its variable, but unique physical and chemical properties are often viewed by society and regulators as pollutants, but many have used these materials in coastal nourishment, land or wetland creation, construction materials and for soil improvements as soil amendment (Sigua, 2005; Sigua et al., 2003, 2004a, 2004b, 2005, 2006). Environmental impact assessment is an important pre-requisite to many dredging initiatives. Current dredged material disposal alternatives have several limitations (Fitzgerald and Pederson, 2001; MacDonald, 1994). Options for dealing with lake-dredged materials include leaving them alone, capping them with clean sediments, placing them in confined facilities, disposing of them at upland sites, treating them chemically, or using them for wetlands creation and other beneficial uses (Sigua et al., 2004b; Adams and Pederson, 2001; Patel et al., 2001; Krause and McDonnell, 2000; Gambrel et al., 1978).

The prohibition of dumping lake-dredged materials and biosolids in streams and oceans, diminishing land fill space, higher landfill costs and concerns over air pollution from incineration of wastes have contributed to a strong public interest in finding alternative, environmentally sound solutions for disposal methods (National Dredging Team, 2003; Krause and McDonnell, 2000; APHA, 1989). Disposal of these materials may create major economic and environmental problem, but countries around the world are committing increasing resources to find effective long-term solutions. The most important step in evaluating the biosolids and lake-dredged materials application alternatives is to determine whether these materials are suitable for agricultural land (Wenning and Woltering, 2001). Therefore, the biosolids and lake-dredged materials should be analyzed carefully and thoroughly to evaluate their quality. The parameters most commonly measured must include the percentage of total solids, total nitrogen ammonium and nitrate nitrogen, total phosphorus and potassium, and total cadmium, copper, nickel, lead, and zinc. Other elements and metals like chromium and mercury are of equal importance and may also need to be measured because industry is contributing high levels of these chemicals into the sewer system. This means that before biosolids and lake-dredged materials can be used commercially in our cropping and livestock systems, they must be shown that they are safe for the environment as well as beneficial for agriculture production. Recycling biosolids and lake-dredged materials to pasture-based animal production is quite productive as alternative nutrient sources for forage production. Speir et al. (2003) investigated the application of large quantities of raw sewage sludge to poor quality pastureland developed on coastal dune sands and found little effect on soil biochemical properties, either adverse or beneficial. Perennial grass can be a good choice for repeated applications of biosolids and lake-dredged materials.

The cow-calf (Bos taurus) industry in subtropical United States and other parts of the world depends almost totally on grazed pasture areas. Thus, the establishment of complete, uniform stand of bahiagrass in a short time period is vital economically. Failure to obtain a high-quality bahiagrass stand early means the loss of not only the initial investment costs, but also production and its cash value. Forage production often requires significant inputs of lime, nitrogen fertilizer and less frequently of phosphorus and potassium fertilizers. Domestic wastewater sludge or sewage sludge, composted urban plant debris, waste lime, phosphogypsum and dredged materials are examples of materials that can be used for fertilizing and liming pastures. Beef cattle producers throughout the United States need better forage management systems to reduce input costs and protect environmental quality. This is particularly true in the 11 million hectares classified as grazingland in the subtropical $\left(23.5-30^{\circ} \mathrm{N}\right.$ Lat) United States due to climatically mediated dependence on tropical forages. Throughout the southeastern United States and elsewhere, grazinglands may have considerable variability in soils, climate and growing season, which not only affect the types of forage that can be grown, but also the overall biodiversity, management, and temporal/spatial nutrient dynamics. In the southeastern United States, particularly, Florida, most of the grazing areas are located on flatwood soils. Flatwood soils comprise about 81 million $\mathrm{km}^{2}$ or about $51 \%$ of Florida soils and are dominated by forestry, beef cattle, citrus, vegetable and dairy operations (Botcher et al., 1998).

Additional research on disposal options of lake-dredged materials and biosolids are still much needed to supply information on criteria testing and evaluation of the physical and chemical impacts of these materials at a disposal site, as well as information on many other aspects of dredged and biosolids materials disposal. While preliminary efforts are underway to provide information to establish criteria for land disposal, testing procedures for possible land disposal of contaminated sediments are still in their developing stage. This paper will attempt to discuss briefly the current and future outlook of lake-dredged materials and biosolids efficacy in agriculture and environment of subtropical regions of the United States of America. The lessons learned can provide valuable insights on what could be done in similar agro-ecosystems elsewhere, including Asia and Africa where management will be different, but the principles could be a roadmap to more sustainable intensifications on the use of biosolids and lake-dredged materials in forage-based pastures cow-calf operations.

\subsection{Lake-dredged materials}

Rivers carry suspended sand and soil along with them as they flow toward the ocean. The higher the water velocity, the greater its energy and capacity to move soil, sand and even rocks along with it. As stream or river velocity slows, heavier materials like sand and gravel, will settle out first. Silt and clay particles, being light in weight, do not settle out until the river has lost most of its energy. Material that falls to the bottom is called sediments (Fig. 1). If enough sediment deposits to build a shallow spot on the river or ocean bottom, it forms shoals. A shoal in a navigation channel that causes the bottom to become shallower is safety hazard.

Dredging (Figs. 2 and 3 ) is the process of removing materials (sediment, debris and organic matter) from the bottom of a water body in order to make it deeper. Additional depth 


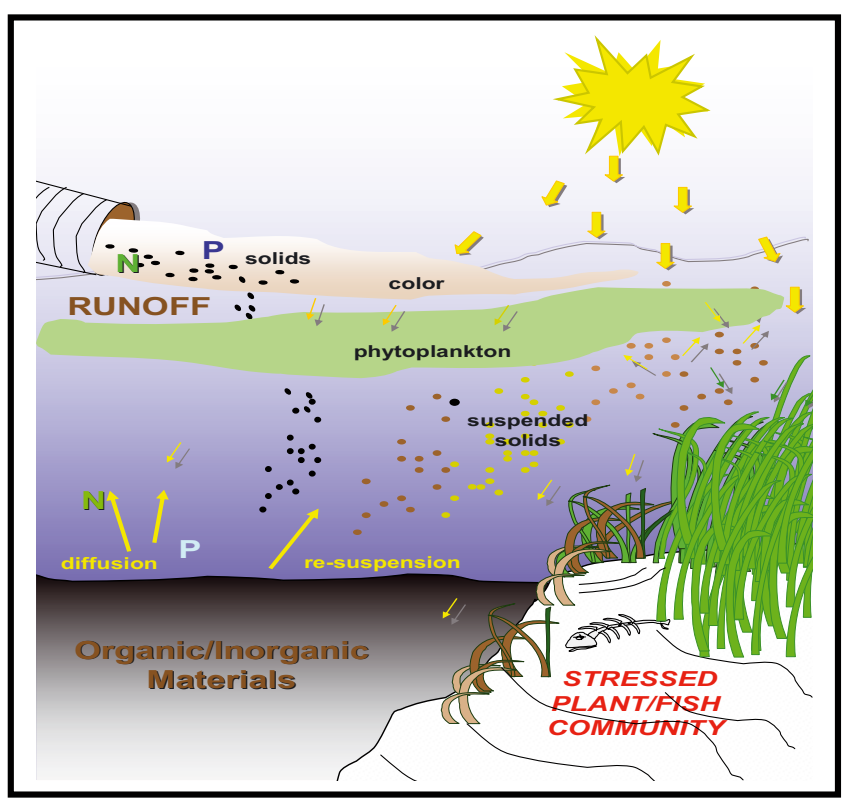

Figure 1. Typical sedimentation process, building up shallow spot called shoals.

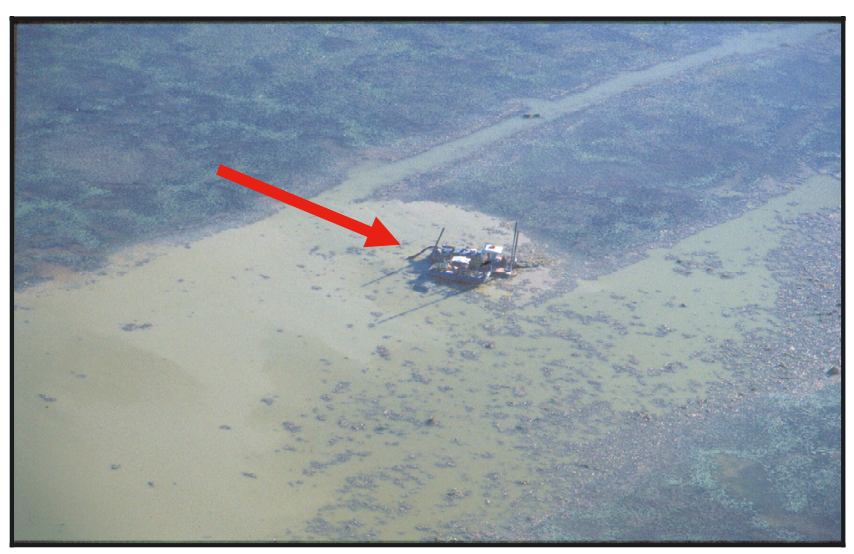

Figure 2. Typical dredging equipment at the middle of the lake.

in estuaries is usually needed to allow for commercial and/or recreational water traffic such as oil tankers, other cargo ships, tour boats, ferries and larger power or sailboats. The build up of sediments is a natural process that is a result of weathering or erosion of the land due to rainfall. Rainfall carries small particles to streams and rivers. In a flowing stream the particles are suspended in the fresh water. However, when the particles reach quiet water the energy to keep them suspended is no longer present. Then gravity and density take over, and the sediments settle to the bottom where they collect. Over time they are eventually buried by the continuous delivery of new sediment from the watershed.

Table I shows some selected properties of dredged materials from Lake Panasoffkee in Florida, USA (Fig. 3). These lakedredged sediments that are typical in most lakes in Florida had high $\mathrm{Ca}\left(\right.$ as $\left.\mathrm{CaCO}_{3}\right)$ content of $828 \pm 2.1 \mathrm{~g} \mathrm{~kg}^{-1}$ and an average $\mathrm{pH}$ of $7.8 \pm 0.2$ (Tab. I). The $\mathrm{Mg}$ content of the dredged

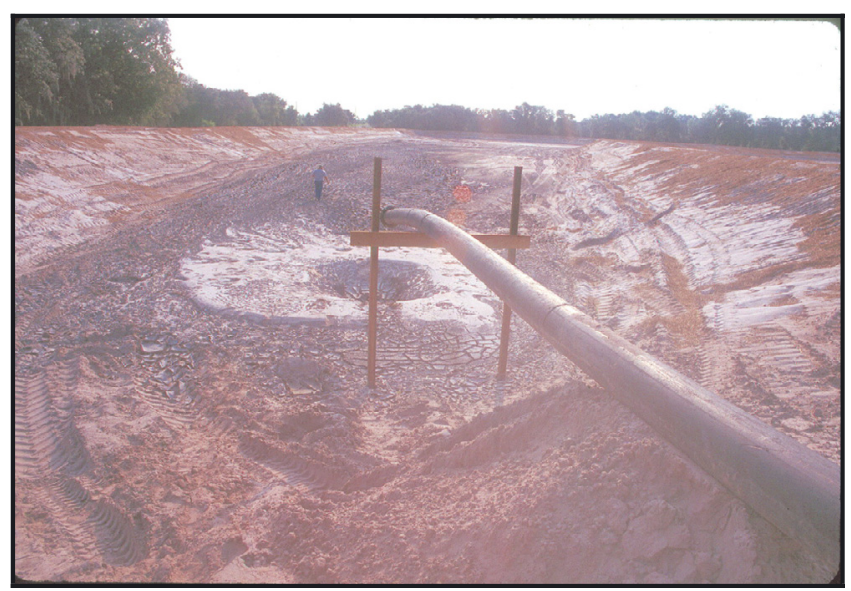

Figure 3. Lake-dredged materials being delivered and deposited at temporary containment area.

Table I. Selected chemical properties of typical lake-dredged materials from Lake Panasoffkee, Sumter County, FL.

\begin{tabular}{|c|c|c|c|}
\hline Parameter & Unit & $\begin{array}{c}\text { Dredged } \\
\text { materials }\end{array}$ & $\begin{array}{l}\text { Analytical } \\
\text { method }\end{array}$ \\
\hline $\mathrm{pH}$ & $\mathrm{pH}$ unit & $7.8 \pm 0.2$ & EPA150.1 \\
\hline Organic Carbon (OC) & $\mathrm{g} \mathrm{kg}^{-1}$ & $127.0 \pm 1.5$ & EPA9060 \\
\hline Potassium (K) & $\mathrm{mg} \mathrm{kg}^{-1}$ & $4.3 \pm 1.8$ & EPA6020 \\
\hline Total Phosphorus (TP) & $\mathrm{mg} \mathrm{kg}^{-1}$ & $1.6 \pm 1.2$ & EPA6010 \\
\hline Total Nitrogen (TKN) & $\mathrm{mg} \mathrm{kg}^{-1}$ & $6.9 \pm 0.3$ & EPA351.2 \\
\hline Nitrate-N & $\mathrm{mg} \mathrm{kg}^{-1}$ & $0.2 \pm 0.05$ & EPA351.1 \\
\hline Nitrite-N & $\mathrm{mg} \mathrm{kg}^{-1}$ & $0.3 \pm 0.05$ & EPA351.1 \\
\hline $\mathrm{Ca}\left(\right.$ as $\left.\mathrm{CaCO}_{3}\right)$ & $\mathrm{g} \mathrm{kg}^{-1}$ & $828 \pm 2.1$ & ASTM C25-95 \\
\hline $\mathrm{Mg}\left(\right.$ as $\left.\mathrm{MgCO}_{3}\right)$ & $\mathrm{g} \mathrm{kg}^{-1}$ & $9 \pm 3.0$ & ASTM C25-95 \\
\hline Lead $(\mathrm{Pb})$ & $\mathrm{mg} \mathrm{kg}^{-1}$ & $5.2 \pm 1.3$ & EPA6020 \\
\hline Zinc (Zn) & $\mathrm{mg} \mathrm{kg}^{-1}$ & $7.0 \pm 0.6$ & EPA6020 \\
\hline Arsenic (As) & $\mathrm{mg} \mathrm{kg}^{-1}$ & $4.4 \pm 0.1$ & EPA6020 \\
\hline Copper $(\mathrm{Cu})$ & $\mathrm{mg} \mathrm{kg}^{-1}$ & $8.7 \pm 1.2$ & EPA6020 \\
\hline Iron $(\mathrm{Fe})$ & $\mathrm{mg} \mathrm{kg}^{-1}$ & $710.0 \pm 1.3$ & EPA6020 \\
\hline Mercury $(\mathrm{Hg})$ & $\mathrm{mg} \mathrm{kg}^{-1}$ & $0.01 \pm 0.02$ & EPA7471 \\
\hline Selenium (Se) & $\mathrm{mg} \mathrm{kg}^{-1}$ & $0.02 \pm 0.02$ & EPA6020 \\
\hline Cadmium (Cd) & $\mathrm{mg} \mathrm{kg}^{-1}$ & $2.5 \pm 0.1$ & EPA6020 \\
\hline Nickel (Ni) & $\mathrm{mg} \mathrm{kg}^{-1}$ & $14.6 \pm 6.4$ & EPA6020 \\
\hline
\end{tabular}

Source: Sigua G.C., Holtkamp M.L., Coleman S.W. (? ), ESPR - Environ. Sci. Pollut. Res. 11, 394-399.

sediment was about $9.0 \pm 3.0 \mathrm{~g} \mathrm{~kg}^{-1}$, while OC level was about $127.0 \pm 1.5 \mathrm{~g} \mathrm{~kg}^{-1}$. The TP, TKN, and $\mathrm{K}$ contents of the lake-dredged materials were relatively low with mean concentrations of $1.6 \pm 1.2,6.9 \pm 0.3$, and $4.3 \pm 1.8 \mathrm{mg} \mathrm{kg}^{-1}$, respectively (Tab. I). Average values for $\mathrm{Pb}, \mathrm{Zn}, \mathrm{As}, \mathrm{Cu}, \mathrm{Hg}$, $\mathrm{Se}, \mathrm{Cd}$, and $\mathrm{Ni}$ of $5.2 \pm 1.3,7.0 \pm 0.6,4.4 \pm 0.1,8.7 \pm 1.2$, $0.01 \pm 0.02,0.02 \pm 0.02,2.5 \pm 0.1$, and $14.6 \pm 6.4 \mathrm{mg} \mathrm{kg}^{-1}$, respectively, were below the threshold effect levels and the probable effect levels published by the Florida Department of Protection (McDonald, 1994). The average concentration of $\mathrm{Cd}$ $\left(2.5 \pm 0.1 \mathrm{mg} \mathrm{kg}^{-1}\right)$ was higher than the threshold effect levels, but lower than the probable effect levels. Since Cd level was below the probable effect levels value, the use of dredged-lake materials was still warranted because $\mathrm{Cd}$ level would not result 
to adverse biological effects (Tab. I). Threshold effect levels represents the concentrations of sediment-associated contaminants that are considered to cause significant hazards to aquatic organisms, while probable effect levels represents the higher limit of the range of the contaminant concentrations that are usually or always associated with adverse biological effects. Additionally, the United States Environmental Protection Agency's pollutant concentration limit of the class B sludge for $\mathrm{Cd}$ is $39 \mathrm{mg} \mathrm{kg}^{-1}$, which is about 10 -fold higher than the concentration of $\mathrm{Cd}$ in lake-dredge materials that were used in the study. The absence of contaminations and based on nitrogen and phosphorus composition of lake-dredge materials, these materials can be used as low-grade nitrogen and phosphorus fertilizers and also as source of calcium.

\subsubsection{Beneficial use alternatives of lake-dredged materials: examples}

The most common dredged material disposal methods are capping, land creation and improvement, topsoil creations and enhancement, beach and littoral nourishment, construction materials, and habitat restoration.

(a) Capping - is the placement of clean or relatively clean dredged materials on top of other land areas or in aquatic environments. The lake-dredged materials serve as a "caps" on top of other land materials.

(b) Land creation/improvement - Land creation or improvement includes the building of dikes or berm for shore protection, filling, raising and protecting submerged and low-lying areas; and applying material to areas where the quality of existing land is poor, such as mine land or brown fields' reclamation.

(c) Topsoil creation/enhancement - this usually involves allowing dredged materials to dry out and applying it alone or mixing it with other materials to make topsoil. Dredged materials are commonly composed of silt, clay and organic matter, which are all important components of topsoil.

(d) Beach/littoral nourishment - Beach/littoral nourishment is the placement of dredged materials along the shore or in the near shore area to provide a source of nourishment for natural sand (littoral) movement or recreational beach improvement and creation.

(e) Construction materials - Construction materials can use the sand portion of dredged materials in road construction and riprap. Dredged materials can also be used as ingredients in the manufacture of bricks, ceramics and concrete.

(f) Habitat restoration - Habitat restoration using dredged material can occur in aquatic, wetland, or upland environments. Strategic placement of dredged materials can also be used to restore and establish wetlands and to create aquaculture ponds for fisheries.

\subsection{Sewage sludge or biosolids}

Wastewater treatment plants commonly process domestic sewage to produce clean "effluent" water. The treatment re-
Table II. Selected characteristics of two types of biosolids.

\begin{tabular}{lcc}
\hline \multirow{2}{*}{ Characteristics } & \multicolumn{2}{c}{ Type of biosolids } \\
\cline { 2 - 3 } & Anaerobically digested & Lime stabilized \\
\hline Solids $(\mathrm{g} / \mathrm{kg})$ & 250 & 250 \\
Nitrogen $(\mathrm{N}, \mathrm{g} / \mathrm{kg})$ & 56 & 38 \\
Phosphorus $(\mathrm{P}, \mathrm{g} / \mathrm{kg})$ & 22 & 10 \\
Potassium $(\mathrm{K}, \mathrm{g} / \mathrm{kg})$ & 2 & 4 \\
Copper $(\mathrm{Cu}, \mathrm{ug} / \mathrm{g})$ & 566 & 236 \\
Molybdenum $(\mathrm{Mo}, \mathrm{ug} / \mathrm{g})$ & 23 & 5 \\
Zinc $(\mathrm{Zn}, \mathrm{ug} / \mathrm{g})$ & 1484 & 321 \\
Arsenic $(\mathrm{As}, \mathrm{ug} / \mathrm{g})$ & 4 & 1 \\
Cadmium $(\mathrm{Cd}, \mathrm{ug} / \mathrm{g})$ & 11 & 4 \\
Chromium $(\mathrm{Cr}, \mathrm{ug} / \mathrm{g})$ & 91 & 10 \\
Lead $(\mathrm{Pb}, \mathrm{ug} / \mathrm{g})$ & 195 & 17 \\
Nickel $(\mathrm{Ni}, \mathrm{ug} / \mathrm{g})$ & 59 & 33 \\
Mercury $(\mathrm{Hg}, \mathrm{ug} / \mathrm{g})$ & 2 & 2 \\
Selenium $(\mathrm{Se}, \mathrm{ug} / \mathrm{g})$ & 3 & 1 \\
pH & 8 & 12 \\
\hline
\end{tabular}

Source: Muchovej R.M., Obreza. T.A. (2001) Biosolids: are these residuals all the same? IFAS, University of Florida, Gainesville, FL.

moves solid materials from the wastewater. These solid materials have to be removed periodically to keep the facilities operating properly. The collected materials, called "residuals" or commonly called "biosolids". Sewage sludge becomes biosolids when it undergoes pathogen control treatment that meets federal and state biosolids regulatory requirements, followed by land application to beneficially recycle it (Obreza and O'Connor, 2003).

There are two types of biosolids produced in Florida based on the stabilization process: (a) lime-stabilized; and (b) stabilized by other processes (chemical, physical, or biological). The stabilization process may significantly alter the nutrient composition of the resulting biosolids (Muchovej and Obreza, 2004). Most biologically stabilized materials undergo an aerobic and anaerobic digestion process. The typical compositions of lime-stabilized and anaerobically-digested biosolids are shown in Table II.

Agricultural uses of biosolids that meet strict quality criteria have been shown to produce significant improvements in crop growth and yield when applied at recommended rates. Sewage sludge or biosolids being derived from organic waste contain a variety of nutrients, which can be used by plants, and organic matter that improves the soil. Biosolids also contain small amounts of contaminants that can limit how they are used. Before biosolids can be applied to land, treatment must be provided to destroy disease-causing organisms (pathogens). Part 503 of the US EPA contain the established pollutant limits that are designed to protect both human health and the environment under worst-case exposure conditions (Smith, 1997). Under both the federal and state regulations, biosolids are classified as either Class A or Class B for pathogen reduction (Tab. III). Class AA received the highest degree of treatment for pathogen reduction and also meets the most stringent pollutant limits. "Ceiling concentrations" were established to prevent land application of residuals with excessive levels of pollutants. If the limit for any one pollutant is exceeded; the 
Table III. Pollutant limits in Federal and State regulations.

\begin{tabular}{|c|c|c|c|c|c|c|}
\hline Pollutants & $\begin{array}{c}\text { Part } 503 \\
\text { Table I } \\
\text { Ceiling conc. } \\
(\mathrm{mg} / \mathrm{kg})\end{array}$ & $\begin{array}{c}\text { Chapter } \\
\text { 62-640, FAC } \\
\text { Ceiling conc. } \\
(\mathrm{mg} / \mathrm{kg})\end{array}$ & $\begin{array}{c}\text { Part } 503 \\
\text { Table II } \\
\text { Cumulative loading } \\
\mathrm{kg} / \mathrm{ha} \text { ) }\end{array}$ & $\begin{array}{c}\text { Chapter } \\
\text { 62-640, FAC } \\
\text { Cumulative loading } \\
(\mathrm{kg} / \mathrm{ha})\end{array}$ & $\begin{array}{c}\text { Part } 503 \\
\text { Table III } \\
\text { Exceptional quality* } \\
(\mathrm{mg} / \mathrm{kg})\end{array}$ & $\begin{array}{c}\text { Chapter } \\
\text { 62-640, FAC } \\
\text { Class AA } \\
(\mathrm{mg} / \mathrm{kg})\end{array}$ \\
\hline Arsenic & 75 & - & 41 & - & 41 & - \\
\hline Cadmium & 85 & 100 & 39 & 4.9 & 39 & 30 \\
\hline Copper & 4300 & 3000 & 1500 & 140 & 1500 & 900 \\
\hline Lead & 840 & 1500 & 300 & 560 & 300 & 1000 \\
\hline Mercury & 57 & - & 17 & - & 17 & - \\
\hline Molybdenum & 75 & - & - & - & - & - \\
\hline Nickel & 420 & 500 & 420 & 140 & 420 & 100 \\
\hline Selenium & 100 & - & 100 & - & 100 & - \\
\hline Zinc & 7500 & 10000 & 2800 & 280 & 2800 & 1800 \\
\hline
\end{tabular}

Source: Smith L. (1997) Regulations affecting the beneficial use of residuals, p. 6, Florida Department of Environmental Protection, Tallahassee, FL.

residuals cannot be applied to the land. Table III lists the federal and state pollutant limits for ceiling concentrations and cumulative loadings. If cumulative loading limit is reached for any pollutant, no further application is allowed at the site. Also lists in Table III are the limits for the highest classification of residuals. Under the federal rule, the highest classification is known as the "exceptional quality". The highest classification in the state rule is "Class AA".

\subsubsection{Biosolids as nutrient source}

Biosolids usually are applied at rates designed to supply crops with adequate nitrogen. They contain a substantial amount of nitrogen (typically 3 to $6 \%$ by weight). The nitrogen is not immediately available to crops, but is released slowly by biological activity. Since biosolids are produce and handled by different processes at different treatment plants, it is important to know if those treatment processes affect how much nitrogen becomes available to plants. Table IV shows the typical macronutrient contents of biosolids produced by Pacific Northwest and southern states wastewater treatment facilities. Nutrients in municipal residuals produced annually in the United States account for about $2.5 \%$ of the total N, 6\% of the $\mathrm{P}$, and $0.5 \%$ of the $\mathrm{K}$ applied on farms each year (Muse et al., 1991).

\subsubsection{Potential problems: fertilizing with biosolids}

Excess nutrients applied to crops have the potential to reach either groundwater or surface water. Nitrogen has the tendency to move towards groundwater in the form of nitrate, which moves freely with water as it flows through the soil. Phosphorus can flow into surface water as particulate matter with eroding sediments. Successful residuals application programs use several of the following nutrient management practices to keep nutrients in the root zone so they can be utilized by crop (Kidder, 1995): (1) Monitoring N concentration of the residuals and accurate record-keeping of rates applied so that the capacity of the soil and crop to assimilate the nutrients is not
Table IV. Properties of wastewater residuals from Pacific Northwest and from several Southern States.

\begin{tabular}{lccccc}
\hline Property & \multicolumn{3}{c}{$\begin{array}{c}\text { Pacific Northwest } \\
\text { States range }\end{array}$} & $\begin{array}{c}\text { Several Southern } \\
\text { States range }\end{array}$ \\
\cline { 2 - 6 } & Unit Low & High & Low & High \\
\hline Organic Matter $^{b}$ & $\mathrm{~g} / \mathrm{kg}$ & 450 & 700 & & 7.0 \\
$\mathrm{pH}$ & & & & 5.4 & 75 \\
Nitrogen & $\mathrm{g} / \mathrm{kg}$ & 30 & 80 & 6 & 53 \\
Phosphorus & $\mathrm{g} / \mathrm{kg}$ & 6 & 13 & 1 & 60 \\
Calcium & $\mathrm{g} / \mathrm{kg}$ & 10 & 40 & 1 & 50 \\
Magnesium & $\mathrm{g} / \mathrm{kg}$ & 4 & 8 & 1 & 10 \\
Potassium & $\mathrm{g} / \mathrm{kg}$ & 1 & 6 & 1 & 11 \\
Sulfur & $\mathrm{g} / \mathrm{kg}$ & & 11 & 11 \\
Iron & $\mathrm{g} / \mathrm{kg}$ & \multicolumn{3}{c}{ Source: } & Sources: (King et al., 1986; \\
& \multicolumn{4}{c}{ (Sullivan D., 1998) } & Muse et al., 1991) \\
\hline
\end{tabular}

a The usual nutrient concentration range includes approximately $80 \%$ of the biosolids analyses reported. Biosolids composts and alkalinestabilized biosolids were not included in the calculation of the usual nutrient concentration range.

${ }^{\mathrm{b}}$ Organic matter determined by loss on ignition (volatile solids).

exceeded; (2) Applying residuals shortly before the peak nutrient demands of the crop to maximize uptake of mineralized $\mathrm{N}$; (3) Incorporating residuals into the soil soon after application, which greatly reduces the potential for $\mathrm{P}$ losses in the surface runoff; and (4) Overseeding an annual cool-season forage crop into a perennial grass to provide a crop for nutrient uptake during times when the perennial is dormant. A sample calculation for a wastewater residuals application is given below.

\section{Assume:}

(a) The residuals to be used contain $4 \%$ total $\mathrm{N}$ on dry weigh basis. solids.

(b) The residuals are a cake material containing $25 \%$

(c) The residuals are to be surface-applied to a foragebased pasture for the first time.

(d) The desired fertilization rate is $70 \mathrm{~kg}$ of plantavailable $\mathrm{N}$ per ha. 


\section{Calculations:}

(a) $0.04 \mathrm{~kg}$ total $\mathrm{N}$ per $\mathrm{kg}$ dry residuals $\times 0.25 \mathrm{~kg}$ dry residuals per $\mathrm{kg}$ cake residuals $\times 1000 \mathrm{~kg}$ per ton $=10 \mathrm{~kg}$ total $\mathrm{N}$ per ton of cake residuals.

(b) Only $50 \%$ of the total $\mathrm{N}$ is assumed to be plantavailable, so there are $5 \mathrm{~kg}$ of available $\mathrm{N}$ in each ton of cake residuals.

(c) $70 \mathrm{~kg} \mathrm{~N}$ needed per ha $/ 5 \mathrm{~kg} \mathrm{~N}$ per ton of cake residuals $=14$ tons of cake residuals per ha.

\section{BIOSOLIDS AND LAKE-DREDGED MATERIALS RECYCLING TO PASTURE-BASED AGRICULTURE: RESEARCH PERSPECTIVES (FLORIDA EXPERIENCES)}

\subsection{Lake-dredged materials}

\subsubsection{Experimental design and methods}

This field study was adjacent to the Coleman Landing spoil disposal site in Sumter County, FL. Each plot $\left(961 \mathrm{~m}^{2}\right)$ was excavated to a depth of about $28 \mathrm{~cm}$, and existing natural soil (NS) and organic materials were completely removed. Excavated NS materials were placed at the south end of the test plots. Existing vegetation from each plot was totally removed prior to backfilling each plot with different ratios of NS and lake-dredge materials (LDM): (100\% NS + 0\% LDM); $(75 \% \mathrm{NS}+25 \% \mathrm{LDM}) ;(50 \% \mathrm{NS}+50 \% \mathrm{LDM}) ;(25 \% \mathrm{NS}$ + 75\% LDM); and (0\% NS + 100\% LDM). These ratios of NS to LDM represent the treatment combinations of LDM0; LDM25; LDM50; LDM75; and LDM100, respectively. Natural soils that were excavated were backfilled to each plot along with lake-dredged materials that were hauled from the adjacent settling pond. The total amount of lake-dredged materials and natural soils that was placed back on each test plot was in accordance with the different ratios of lake-dredged materials and natural soils that were described above. After mixing the natural soils and lake-dredged materials, each of the test plots was disked to a uniform depth of $28 \mathrm{~cm}$. Plots were disked in an alternate direction until lake-dredged materials and natural soils were uniformly mixed. Each plot was seeded with bahiagrass at a rate of $6 \mathrm{~kg} \mathrm{plot}^{-1}$, followed by dragging a section of chain link fence across each test plot to ensure that bahiagrass seeds were in good contact with the natural soils and lakedredged materials. Field layout was based on the principle of a completely randomized block design with four replications.

Three sub-samples of soils $(0-20 \mathrm{~cm}$ depth) were taken from each plot using a $15 \mathrm{~cm}$ steel bucket-type hand auger. Soil samples were air-dried and passed through a $2 \mathrm{~mm}$ mesh sieve prior to soil chemical extractions. The Mehlich 1 method ( $0.05 \mathrm{~N} \mathrm{HCl}$ in $0.025 \mathrm{~N} \mathrm{H}_{2} \mathrm{SO}_{4}$ ) was used for chemical extraction of soil (Mehlich, 1953). Soil phosphorus and other exchangeable cations $(\mathrm{K}, \mathrm{Ca}, \mathrm{Mg}, \mathrm{Al}, \mathrm{Fe}, \mathrm{Zn}, \mathrm{Mn}, \mathrm{Cu}, \mathrm{Si}$, and $\mathrm{Na}$ ) were analyzed using an Inductively Coupled Plasma (ICP) Spectroscopy. Soil organic matter content was analyzed following the method of Walkley and Black (1934). Soil pH was determined by using 1:2 soils to water ratio (Thomas, 1996).
Several measurements of soil penetrometer resistance (0-20 cm depth) were taken using the Dickey-John Penetrometer (Dickey-John Corp, Auburn, IL). The penetrometer is designed to mimic a plant root, which consists of a 30-degree circular stainless steel cone with a driving shaft and pressure gauge. This penetrometer comes with two cones, one with a base diameter of $2.03 \mathrm{~cm}$ for soft soils and $1.28 \mathrm{~cm}$ for hard soils. The driving shaft is graduated every $7.62 \mathrm{~cm}$ (3 inches) to allow determination of depth of compaction. The pressure gauge indicates pressure in pounds per square inch.

\subsection{Highlights: research results and discussion}

\subsubsection{Effects on soil compaction}

Results have shown the favorable influence that lakedredged materials had on soil penetrometer resistance or soil compaction (Fig. 4). The treatment $\times$ year interaction effect was not significant, but the average soil compaction varied widely $(P \leqslant 0.001)$ with lake-dredged materials application. In 2002 and 2003, soil compaction of plots was lowered significantly as a result of lake-dredged materials additions (Fig. 4). The least compacted soils in 2002 and 2003 were observed from plots with $75 \%$ lake-dredged materials with mean soil compaction of $300 \times 10^{3}$ and $350 \times 10^{3} \mathrm{~Pa}$, respectively. The most compacted soils in 2002 and 2003 were from the control plots with mean soil compaction of $1800 \times 10^{3}$ and 1600 $\times 10^{3} \mathrm{~Pa}$, respectively. The degree of soil compaction in the control plots were comparable with the surrounding natural soils (SNS), but were different and significantly higher than those plots with lake-dredged materials additions.

Penetrometer resistance of soils in plots with LDM50, LDM75, and LDM100 were all comparable among each other in 2002 and in 2003, respectively (Fig. 4). Soil compaction was lowered significantly by the application of lakedredged materials. The least compacted soils in 2002 and 2003 were observed from plots with $75 \%$ lake-dredged materials, while the most compacted soils in 2002 and 2003 were from the control plots ( $0 \%$ lake-dredged materials). These results have shown the favorable influence that lake-dredged materials had on soil compaction. The higher rates of lake-dredged materials application may have had improved soil structure and soil tilth which can promote better water holding capacity, sufficient aeration, and creates more friable soils.

The compaction of agricultural soils is a serious problem and growing concern because the productive capacity of the land could be seriously reduced. A compacted layer within the soil profile may restrict root growth and access to water and nutrients (Follet and Wilkinson, 1995). The structure of fine-textured (typic quartzipsamments) soils in the study area (Coleman Landing) has shown improvement as a result of lake-dredged materials addition. This is largely the result of an increase in the organic matter content and to a lesser extent to the flocculation of calcium-saturated colloids. Application of lake-dredged materials may have had promoted intense biological activity, increased nitrogen fixation by soil microorganisms, and release of component elements by the more rapid 


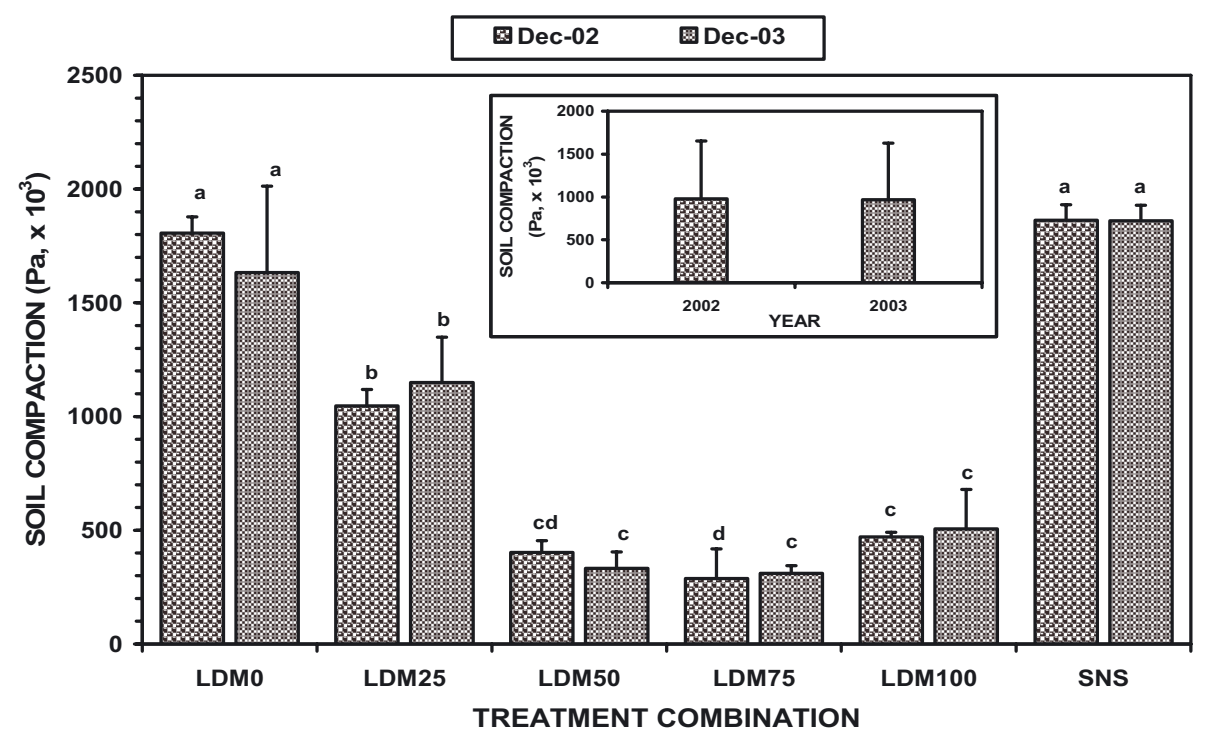

Figure 4. Degree of soil compaction for soils with varying levels of lake-dredged materials. Soil compactions from plots with or without lake-dredged materials are significantly different $(P \leqslant 0.05)$ when superscripts located at top of bars are different.

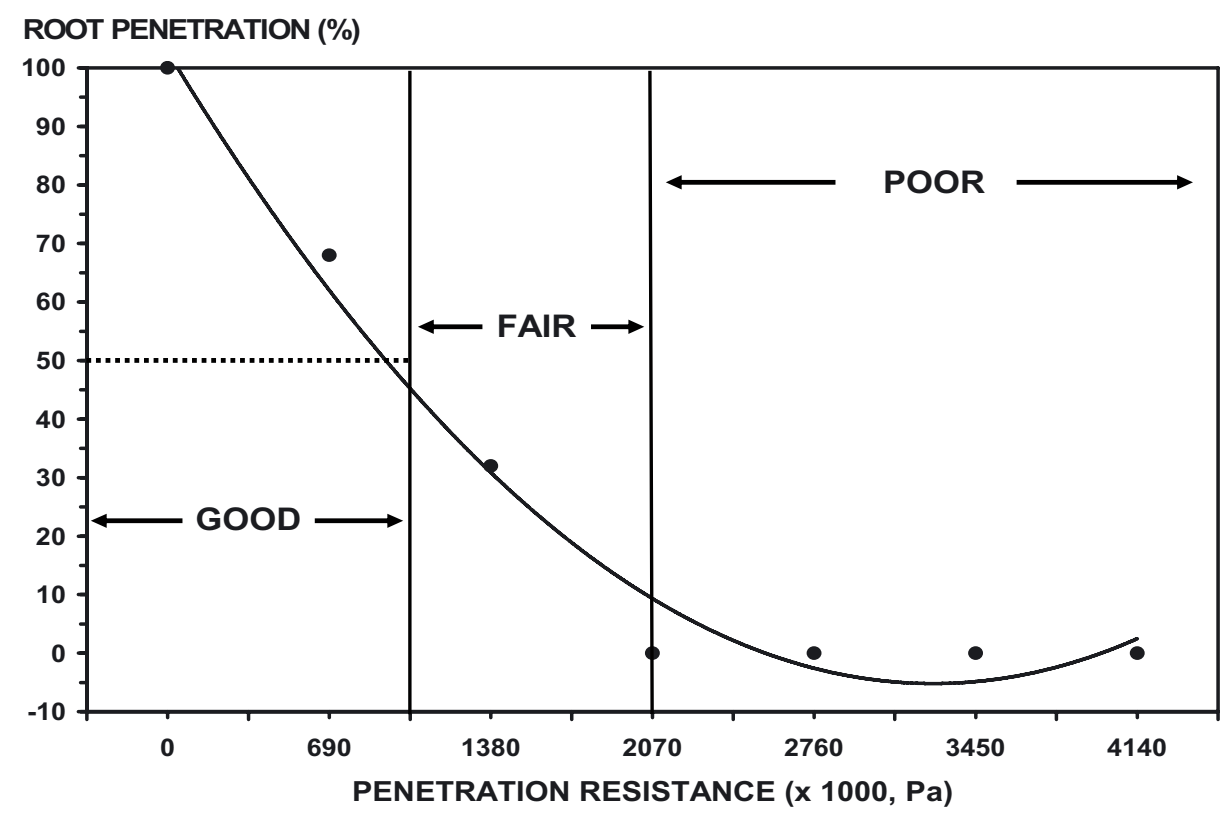

Figure 5. Relationship of root penetration and penetration resistance in soils using penetrometer (Source: Murdock L., Gray T., Higgins F., Wells K. (1995) Soil compaction in Kentucky, Cooperative Extension Service, Univ. Kentucky, Lexington, AGR-161). RP $(\%)=153.1+$ $4.8 \mathrm{x}^{2}-55.2 \mathrm{x}, \mathrm{R}^{2}=0.98$.

decomposition of plant residues (Follet and Wilkinson, 1995; Pearson and Hoveland, 1974).

Penetration resistances of soil treated with lake-dredged materials have values well within the "good" range of root development or penetration. Penetration resistance of about $1035 \times 10^{3} \mathrm{~Pa}$ in soils could result to a root penetration reduction of about $50 \%$, while penetration resistance of greater than $1380 \times 10^{3}$ Pa may result to $80 \%$ to $90 \%$ root penetration reduction (Fig. 5). Penetration resistance of greater than $1380 \times 10^{3}$ $\mathrm{Pa}$ may trigger poor root development if not corrected prop- erly. The use of soil penetrometer, which is designed to mimic a plant root, is one way of monitoring soil compaction.

\subsubsection{Effects on soil chemical properties}

The average soil tests values for $\mathrm{pH}$, total inorganic nitrogen, total phosphorus, potassium, calcium, and magnesium varied significantly $(P \leqslant 0.001)$ among plots amended with different rates of lake-dredged materials within years, but not 
Table V. Average levels of soil pH, TIN, TP, K, Ca, and Mg from beef cattle pasture plots amended with different levels of lake-dredged materials in 2002, 2003, 2004, and in 2005.

\begin{tabular}{|c|c|c|c|c|c|c|}
\hline $\begin{array}{l}\text { Application rates } \\
\left(\mathrm{g} \mathrm{kg}^{-1}\right)\end{array}$ & $\mathrm{pH}$ & $\operatorname{TIN}^{\dagger}$ & $\mathrm{TP}^{\ddagger}$ & $\begin{array}{c}\mathrm{K}^{\ddagger} \\
-\left(\mathrm{mg} \mathrm{kg}^{-1}\right)\end{array}$ & $\mathrm{Ca}^{\ddagger}$ & $\mathrm{Mg}^{\ddagger}$ \\
\hline \multirow[t]{2}{*}{ Initial (all treatments) } & $5.9 \pm 0.01$ & $2.9 \pm 1.5$ & $20.6 \pm 8.9$ & $39.9 \pm 11.6$ & & \\
\hline & \multicolumn{6}{|c|}{2002} \\
\hline 0 & $5.9 \pm 0.006 \mathrm{~d}^{\S}$ & $0.16 \pm 0.02 \mathrm{c}$ & $5.08 \pm 0.81 \mathrm{a}$ & $3.6 \pm 0.6 \mathrm{a}$ & $105 \pm 5.4 \mathrm{~b}$ & $4.3 \pm 2.6 b$ \\
\hline 250 & $7.1 \pm 0.1 \mathrm{c}$ & $0.67 \pm 0.44 b$ & $0.17 \pm 0.13 b$ & $0.9 \pm 0.1 \mathrm{c}$ & $1962 \pm 25.8 \mathrm{a}$ & $11.9 \pm 0.7 \mathrm{a}$ \\
\hline 500 & $7.4 \pm 0.005 b$ & $0.91 \pm 0.24 \mathrm{ab}$ & $0.13 \pm 0.02 b$ & $2.8 \pm 1.4 \mathrm{a}$ & $2040 \pm 29.1 \mathrm{a}$ & $13.6 \pm 1.1 \mathrm{a}$ \\
\hline 750 & $7.4 \pm 0.00 \mathrm{~b}$ & $1.34 \pm 0.12 \mathrm{a}$ & $0.06 \pm 0.02 b$ & $1.8 \pm 1.0 \mathrm{bc}$ & $2008 \pm 87.1 \mathrm{a}$ & $14.6 \pm 1.7 \mathrm{a}$ \\
\hline 1000 & $7.5 \pm 0.06 \mathrm{a}$ & $0.87 \pm 0.13 b$ & $0.14 \pm 0.04 b$ & $2.5 \pm 0.7 \mathrm{abc}$ & $2030 \pm 9.2 \mathrm{a}$ & $14.7 \pm 0.6 \mathrm{a}$ \\
\hline \multirow[t]{2}{*}{$\operatorname{LSD}(0.05)$} & 0.11 & 0.44 & 4.53 & 1.60 & 78.10 & 2.80 \\
\hline & \multicolumn{6}{|c|}{2003} \\
\hline 0 & $5.46 \pm 0.08 \mathrm{~d}$ & $0.26 \pm 0.01 \mathrm{c}$ & $6.69 \pm 0.01 \mathrm{a}$ & $21.4 \pm 2.8 \mathrm{c}$ & $348 \pm 40.3 \mathrm{c}$ & $15.1 \pm 0.84 \mathrm{~d}$ \\
\hline 250 & $7.35 \pm 0.10 \mathrm{c}$ & $0.71 \pm 0.44 \mathrm{~b}$ & $1.11 \pm 0.21 b$ & $41.5 \pm 13.4 \mathrm{a}$ & $6534 \pm 10.5 \mathrm{ab}$ & $61.7 \pm 5.6 \mathrm{c}$ \\
\hline 500 & $7.62 \pm 0.08 b$ & $0.96 \pm 0.19 \mathrm{~b}$ & $1.99 \pm 0.14 b$ & $41.9 \pm 11.4 \mathrm{a}$ & $6679 \pm 32.84 a$ & $86.3 \pm 9.5 \mathrm{a}$ \\
\hline 750 & $7.67 \pm 0.08 b$ & $1.40 \pm 0.14 \mathrm{a}$ & $1.69 \pm 0.19 b$ & $36.5 \pm 8.1 \mathrm{ab}$ & $6564 \pm 45.0 \mathrm{a}$ & $92.9 \pm 12.9 \mathrm{a}$ \\
\hline 1000 & $7.77 \pm 0.05 \mathrm{a}$ & $0.91 \pm 0.13 b$ & $1.61 \pm 0.31 b$ & $27.9 \pm 3.8 b c$ & $6236 \pm 44.6 b$ & $74.9 \pm 86 b$ \\
\hline \multirow[t]{2}{*}{$\operatorname{LSD}(0.05)$} & 0.09 & 0.42 & 4.79 & 10.6 & 155.01 & 10.11 \\
\hline & \multicolumn{6}{|c|}{2004} \\
\hline 0 & $5.9 \pm 0.69 b$ & $2.77 \pm 0.19 b$ & $2.26 \pm 0.82 \mathrm{a}$ & $19.3 \pm .1 \mathrm{a}$ & $173 \pm 9.1 b$ & $4.6 \pm 1.5 \mathrm{~d}$ \\
\hline 250 & $7.5 \pm 0.08 \mathrm{a}$ & $61.85 \pm 1.5 \mathrm{a}$ & $0.08 \pm 0.01 \mathrm{~b}$ & $15.9 \pm 1.2 \mathrm{ab}$ & $1268 \pm 7.8 \mathrm{a}$ & $7.2 \pm 0.8 \mathrm{c}$ \\
\hline 500 & $7.8 \pm 0.06 \mathrm{a}$ & $21.59 \pm 5.26 b$ & $0.04 \pm 0.01 b$ & $5.0 \pm 1.0 \mathrm{ab}$ & $1160 \pm 9.8 \mathrm{a}$ & $8.4 \pm 1.1 b c$ \\
\hline 750 & $7.7 \pm 0.11 \mathrm{a}$ & $28.16 \pm 3.28 \mathrm{ab}$ & $0.06 \pm 0.01 b$ & $2.8 \pm 0.3 b$ & $1155 \pm 5.5 \mathrm{a}$ & $10.4 \pm 0.6 \mathrm{ab}$ \\
\hline 1000 & $7.8 \pm 0.04 \mathrm{a}$ & $26.50 \pm 6.58 b$ & $0.07 \pm 0.04 \mathrm{~b}$ & $6.2 \pm 0.4 \mathrm{ab}$ & $1155 \pm 10.4 \mathrm{a}$ & $12.7 \pm 2.2 \mathrm{a}$ \\
\hline \multirow[t]{2}{*}{$\operatorname{LSD}(0.05)$} & 0.57 & 34.56 & 2.29 & 16.2 & 117.0 & 2.5 \\
\hline & \multicolumn{6}{|c|}{2005} \\
\hline 0 & $5.5 \pm 0.77 b$ & $2.36 \pm 0.67 b$ & $6.99 \pm 0.98 \mathrm{a}$ & $3.48 \pm 0.8 b$ & $44.7 \pm 8.3 \mathrm{c}$ & $1.9 \pm 1.4 b$ \\
\hline 250 & $6.8 \pm 0.96 \mathrm{ab}$ & $2.32 \pm 0.57 b$ & $3.15 \pm 4.31 \mathrm{ab}$ & $1.30 \pm 0.4 b$ & $174 \pm 2.8 b$ & $1.9 \pm 1.4 \mathrm{~b}$ \\
\hline 500 & $7.4 \pm 0.02 \mathrm{a}$ & $24.46 \pm 13.32 b$ & $0.32 \pm 0.05 b$ & $2.56 \pm 0.57 b$ & $156 \pm 2.6 b$ & $2.7 \pm 1.8 \mathrm{ab}$ \\
\hline 750 & $7.3 \pm 0.02 \mathrm{a}$ & $29.26 \pm 3.36 \mathrm{a}$ & $0.18 \pm 0.01 b$ & $14.25 \pm 0.7 .8 \mathrm{a}$ & $318 \pm 10.5 \mathrm{a}$ & $8.8 \pm 2.7 \mathrm{a}$ \\
\hline 1000 & $7.5 \pm 0.02 \mathrm{a}$ & $12.47 \pm 7.83 \mathrm{ab}$ & $0.11 \pm 0.04 \mathrm{~b}$ & $3.06 \pm 0.01 b$ & $301 \pm 12.8 \mathrm{a}$ & $4.8 \pm 1.7 \mathrm{ab}$ \\
\hline $\operatorname{LSD}(0.05)$ & 1.42 & 18.20 & 5.11 & 10.1 & 313.7 & 6.14 \\
\hline
\end{tabular}

Extracted with $2 \mathrm{~N} \mathrm{KCl}$.

Extracted with double acids $\left(0.05 \mathrm{~N} \mathrm{HCl}\right.$ in $\left.0.025 \mathrm{~N} \mathrm{H}_{2} \mathrm{SO}_{4}\right)$.

${ }^{\S}$ Means in each column for each year with common letter (s) are not significantly different at $P \leqslant 0.05$.

affected by the year $\times$ treatment interaction effects (Tab. V). Compared with the control plots, the soils in plots amended with lake-dredged materials exhibited an increase in soil $\mathrm{pH}$, total inorganic nitrogen, calcium, and magnesium in all years. However, levels of soil calcium and magnesium from plots with lake-dredged materials addition were lower in 2005 compared with their average values in 2002, 2003, and 2004. The average calcium levels in soil (averaged across plots with lakedredged materials) in 2002, 2003, and 2004 were 2010; 6503; and $1184 \mathrm{mg} \mathrm{kg}^{-1}$, respectively compared with $237 \mathrm{mg} \mathrm{kg}^{-1}$ in 2005. The levels of calcium show a decline in value in four years.

Addition of lake-dredged materials resulted in higher soil $\mathrm{pH}$ than those plots with no lake-dredged materials. Soil $\mathrm{pH}$ (averaged across plots with lake-dredged materials) of 7.4, 7.6, 7.7, and 7.2 were higher than plots with no lake-dredged materials $(5.9,5.5,5.9$, and 5.5) in 2002, 2003, 2004, and 2005, respectively (Tab. V). Soil test values for total inorganic nitrogen in 2004 and 2005 showed an increasing trend when compared with their levels in 2002 and 2003 for soils treated with lake-dredged materials. The average increase of total inorganic nitrogen in 2004 and 2005 in soils treated with lakedredged materials (averaged across treatments) were 34.5 and $17.1 \mathrm{mg} \mathrm{kg}^{-1}$ compared with 0.94 and $0.99 \mathrm{mg} \mathrm{kg}^{-1}$ in 2002 and 2003 , respectively.

The levels of total phosphorus in soils that were treated with different levels of lake-dredged materials were consistently lower than the soil total phosphorus values in plots with no lake-dredged materials application for all years. The average soil test values for total phosphorus in soils with no lakedredged materials were $5.1,6.7,2.3$, and $6.9 \mathrm{mg} \mathrm{kg}^{-1}$ in 2002 , 2003,2004 , and 2005, respectively. It must be noted that the soil tests values for total phosphorus should not be construed as environmental problems. Their present soil tests values are well below levels considered to be harmful to the environment. Concerns for losses of soil phosphorus by overland flow occur when soil tests values are well below levels considered being harmful to the environment. Concern for losses of soil $\mathrm{P}$ by 
Table VI. Average level of $\mathrm{Zn}, \mathrm{Mn}, \mathrm{Cu}, \mathrm{Fe}$, and $\mathrm{Al}$ of sandy soils from beef cattle pasture plots amended with different amounts of lake-dredged materials in 2002, 2003, 2004, and in 2005.

\begin{tabular}{|c|c|c|c|c|c|}
\hline $\begin{array}{l}\text { Application rate } \\
\left(\mathrm{g} \mathrm{kg}^{-1}\right)\end{array}$ & $\mathrm{Zn}^{\dagger}$ & $\mathrm{Mn}^{\dagger}$ & $\begin{array}{c}\mathrm{Cu}^{\dagger} \\
-\left(\mathrm{mg} \mathrm{kg}^{-1}\right) \\
\end{array}$ & $\mathrm{Fe}^{\dagger}$ & $\mathrm{Al}^{\dagger}$ \\
\hline Initial (all treatments) & $0.40 \pm 0.3$ & $1.30 \pm 0.7$ & $\begin{array}{c}0.20 \pm 0.1 \\
2002\end{array}$ & $4.90 \pm 0.1$ & $83.4 \pm 17.1$ \\
\hline 0 & $0.69 \pm 0.13 \mathrm{a}^{\ddagger}$ & $2.86 \pm 0.39 \mathrm{a}$ & $0.45 \pm 0.05 \mathrm{a}$ & $15.81 \pm 5.59 \mathrm{a}$ & $87.23 \pm 13.28 \mathrm{a}$ \\
\hline 250 & $0.01 \pm 0.006 b$ & $0.35 \pm 0.05 b$ & $0.001 \pm 0.0005 b$ & $0.03 \pm 0.01 b$ & $0.19 \pm 0.24 b$ \\
\hline 500 & $0.006 \pm 0.001 b$ & $0.31 \pm 0.01 b$ & $0.002 \pm 0.001 b$ & $0.002 \pm 0.001 b$ & $0.03 \pm 0.02 b$ \\
\hline 750 & $0.007 \pm 0.0006 \mathrm{~b}$ & $0.25 \pm 0.01 b$ & $0.002 \pm 0.001 b$ & $0.002 \pm 0.001 b$ & $0.01 \pm 0.00 \mathrm{~b}$ \\
\hline 1000 & $0.005 \pm 0.00 \mathrm{~b}$ & $0.34 \pm 0.04 b$ & $0.003 \pm 0.001 b$ & $0.003 \pm 0.000 \mathrm{~b}$ & $0.04 \pm 0.02 b$ \\
\hline $\operatorname{LSD}(0.05)$ & 0.10 & 0.32 & $\begin{array}{r}0.04 \\
2003\end{array}$ & 4.56 & 10.80 \\
\hline 0 & $0.93 \pm 0.14 \mathrm{a}$ & $2.66 \pm 0.24 \mathrm{a}$ & $1.04 \pm 0.08 \mathrm{a}$ & $23.17 \pm 9.1 \mathrm{a}$ & $46.31 \pm 9.1 \mathrm{a}$ \\
\hline 250 & $0.13 \pm 0.02 \mathrm{c}$ & $0.91 \pm 0.06 b$ & $0.00 \pm 0.00 \mathrm{~b}$ & $0.19 \pm 0.06 b$ & $0.58 \pm 0.33 b$ \\
\hline 500 & $0.23 \pm 0.02 b$ & $0.93 \pm 0.95 b b$ & $0.00 \pm 0.00 \mathrm{~b}$ & $0.32 \pm 0.06 \mathrm{~b}$ & $0.16 \pm 0.15 b$ \\
\hline 750 & $0.29 \pm 0.04 b$ & $0.83 \pm 0.09 b$ & $0.00 \pm 0.00 \mathrm{~b}$ & $0.29 \pm 0.07 b$ & $0.13 \pm 0.03 b$ \\
\hline 1000 & $0.24 \pm 0.07 \mathrm{~b}$ & $1.08 \pm 0.16 b$ & $0.00 \pm 0.00 \mathrm{~b}$ & $0.36 \pm 0.08 b$ & $0.14 \pm 0.07 \mathrm{~b}$ \\
\hline $\operatorname{LSD}(0.05)$ & 0.09 & 0.17 & $\begin{array}{c}0.04 \\
2004\end{array}$ & 4.84 & 20.83 \\
\hline 0 & $0.33 \pm 0.04 \mathrm{a}$ & $1.28 \pm 0.11 \mathrm{a}$ & $0.14 \pm 0.11 \mathrm{a}$ & $4.96 \pm 0.78 \mathrm{a}$ & $41.37 \pm 7.14 \mathrm{a}$ \\
\hline 250 & $0.006 \pm 0.001 b$ & $0.14 \pm 0.11 \mathrm{~b}$ & $0.003 \pm 0.001 b$ & $0.000 \pm 0.00 \mathrm{~b}$ & $1.27 \pm 0.18 \mathrm{~b}$ \\
\hline 500 & $0.000 \pm 0.000 \mathrm{~b}$ & $0.06 \pm 0.02 b$ & $0.001 \pm 0.0001 \mathrm{~b}$ & $0.000 \pm 0.00 \mathrm{~b}$ & $1.08 \pm 0.01 \mathrm{~b}$ \\
\hline 750 & $0.000 \pm 0.000 \mathrm{~b}$ & $0.07 \pm 0.01 b$ & $0.002 \pm 0.0001 \mathrm{~b}$ & $0.000 \pm 0.00 \mathrm{~b}$ & $1.06 \pm 0.04 \mathrm{~b}$ \\
\hline 1000 & $0.000 \pm 0.000 \mathrm{~b}$ & $0.08 \pm 0.05 b$ & $0.002 \pm 0.001 \mathrm{~b}$ & $0.000 \pm 0.00 \mathrm{~b}$ & $1.03 \pm 0.07 \mathrm{~b}$ \\
\hline $\operatorname{LSD}(0.05)$ & 0.04 & 2.23 & $\begin{array}{l}0.09 \\
2005\end{array}$ & 0.63 & 11.77 \\
\hline 0 & $0.117 \pm 0.06 \mathrm{a}$ & $0.23 \pm 0.15 \mathrm{a}$ & $0.021 \pm 0.011 \mathrm{a}$ & $0.54 \pm 0.30 \mathrm{a}$ & $51.46 \pm 7.14 \mathrm{a}$ \\
\hline 250 & $0.018 \pm 0.02 \mathrm{~b}$ & $0.09 \pm 0.01 b$ & $0.010 \pm 0.007 \mathrm{~b}$ & $0.32 \pm 0.05 b$ & $11.27 \pm 9.18 b$ \\
\hline 500 & $0.010 \pm 0.01 \mathrm{~b}$ & $0.13 \pm 0.01 \mathrm{~b}$ & $0.012 \pm 0.001 b$ & $0.02 \pm 0.01 \mathrm{~b}$ & $0.23 \pm 0.03 b$ \\
\hline 750 & $0.002 \pm 0.00 \mathrm{~b}$ & $0.08 \pm 0.02 b$ & $0.004 \pm 0.001 b$ & $0.02 \pm 0.00 \mathrm{~b}$ & $0.52 \pm 0.01 \mathrm{~b}$ \\
\hline 1000 & $0.004 \pm 0.00 \mathrm{~b}$ & $0.07 \pm 0.01 \mathrm{~b}$ & $0.013 \pm 0.002 b$ & $0.01 \pm 0.00 \mathrm{~b}$ & $0.49 \pm 0.12 b$ \\
\hline $\operatorname{LSD}(0.05)$ & 0.07 & 0.26 & 2.57 & 0.64 & 33.76 \\
\hline
\end{tabular}

$\dagger$ Extracted with double acids $\left(0.05 \mathrm{~N} \mathrm{HCl}\right.$ in $\left.0.025 \mathrm{~N} \mathrm{H}_{2} \mathrm{SO}_{4}\right)$ as described by Mehlich (1953).

* Means in each column for each year with common letter (s) are not significantly different at $P \leqslant 0.05$.

overland flow occur when soil P exceeded $150 \mathrm{mg} \mathrm{kg}^{-1}$ in the upper 20-cm of soil (Johnson and Eckert, 1995; Sharpley et al., 1996).

Average soil tests values for Mehlich 1 extracted $\mathrm{Zn}, \mathrm{Mn}$, $\mathrm{Cu}, \mathrm{Fe}$, and $\mathrm{Al}$ from plots treated with different levels of lake-dredged materials are shown Table VI. The levels of extractable $\mathrm{Zn}, \mathrm{Mn}, \mathrm{Cu}, \mathrm{Fe}$, and $\mathrm{Al}$ in soils were significantly reduced by lake-dredged materials application and this result was consistent for all years.

The overall results however showed that with increasing application rates of lake-dredged materials, soil test values for extractable $\mathrm{Zn}, \mathrm{Mn}, \mathrm{Cu}, \mathrm{Fe}$, and $\mathrm{Al}$ remained to be statistically comparable from 2002 to 2005 . These initial data suggest that applied lake-dredged materials regardless of application rates would not be source of trace metals in the soil (Tab. VI).

The average levels of extractable $\mathrm{Zn}$ and $\mathrm{Mn}$ (averaged across years) in soils with lake-dredged materials treatments were significantly lower when compared to soils with no lakedredged materials (Tab. VI). Similar trends and comparisons of results were noted for extractable $\mathrm{Cu}, \mathrm{Fe}$, and $\mathrm{Al}$ between plots with lake-dredged materials and plots with no lakedredged materials application in 2002, 2003, 2004, and 2005.
The average levels of $\mathrm{Cu}$ in soils without lake-dredged materials treatment were $0.45,1.04,0.14$, and $0.02 \mathrm{mg} \mathrm{kg}^{-1}$ compared with $0.002,0.000,0.002$, and $0.009 \mathrm{mg} \mathrm{kg}^{-1}$ in 2002, 2003, 2004, and 2005, respectively (Tab. VI).

\subsubsection{Effects on forage yield}

The forage yield of bahiagrass at 112, 238, and $546 \mathrm{Ju}-$ lian days after seeding are shown in Figure 6. Forage yield of bahiagrass varied significantly $(P \leqslant 0.001)$ among plots with lake-dredged materials additions. The greatest forage yield of $673 \pm 233 \mathrm{~kg} \mathrm{ha}^{-1}$ at Julian day 112 was from plots amended with $50 \%$ lake-dredged materials while bahiagrass in plots amended with $100 \%$ lake-dredged materials and $75 \%$ lakedredged materials had the highest forage yield at Julian days 238 and 546 with average forage yield of $3349 \pm 174$ and $4109 \pm 220 \mathrm{~kg} \mathrm{ha}^{-1}$, respectively (Fig. 6). The lowest forage yield of $89 \pm 63,1513 \pm 166$, and $1263 \pm 116 \mathrm{~kg} \mathrm{ha}^{-1}$ were from the control plots for Julian days 112, 238, and 546, respectively (Fig. 6). The average forage yield increase of bahiagrass in plots amended with lake-dredged materials (averaged across treatments) was $512 \%, 82 \%$, and $173 \%$ when compared 


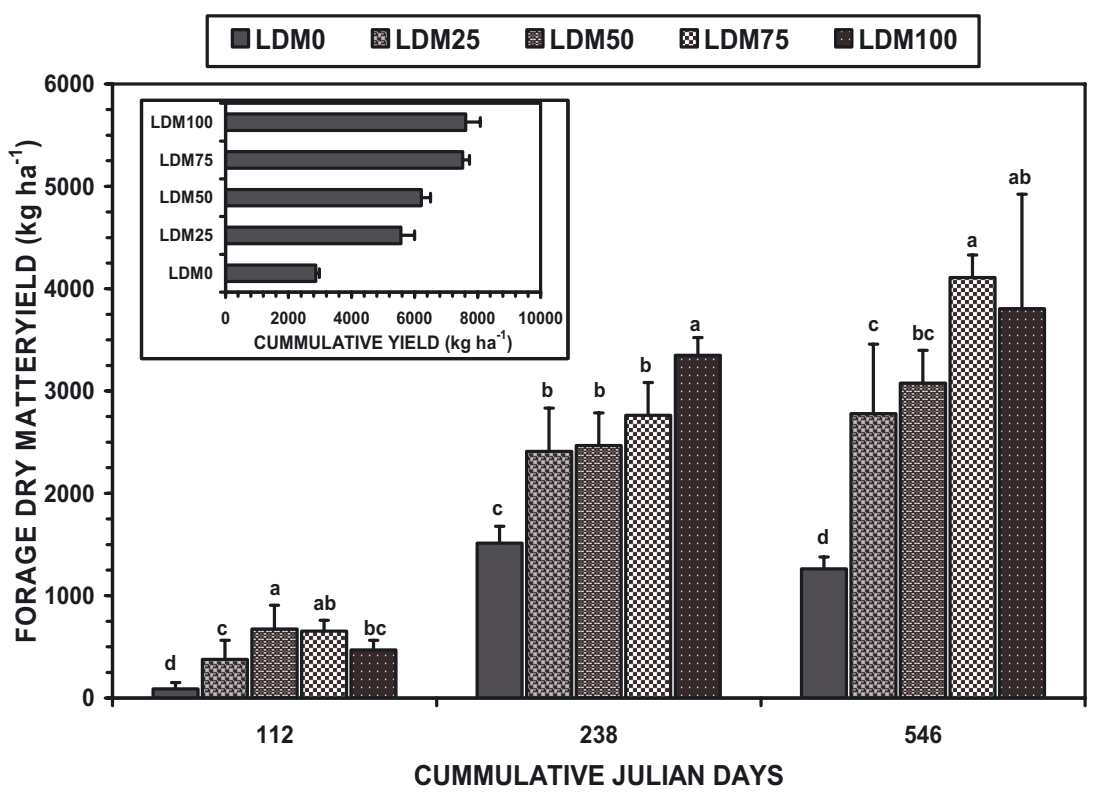

Figure 6. Forage yield of bahiagrass (Julian days 112 to 546) as affected by varying levels of dredged materials application. Forage yield from plots with or without lake-dredged materials are significantly different $(P \leqslant 0.05)$ at Julian days 112,238 , and 546 when superscripts located at top of bars are different. (Source: Sigua et al., 2004b).

with bahiagrass in control plots with $0 \%$ lake-dredged materials for Julian days 112, 238, and 546, respectively (Fig. 6). These data show the favorable influence that lake-dredged materials had on forage yield of bahiagrass during its early establishment in subtropical beef cattle pastures.

Mean forage yield of bahiagrass during Julian day 112 in plots with $50 \%$ lake-dredged materials of $673 \pm 233 \mathrm{~kg} \mathrm{ha}^{-1}$ was not significantly different from that in plots with $75 \%$ lake-dredged materials $\left(654 \pm 106 \mathrm{~kg} \mathrm{ha}^{-1}\right)$, but was greater than that in plots with $25 \%$ lake-dredged materials $(378 \pm$ $185 \mathrm{~kg} \mathrm{ha}^{-1}$ ) and $0 \%$ lake-dredged materials (Fig. 6). For Julian day 238, the greatest forage yield among plots amended with lake-dredged materials was from plots with $100 \%$ lakedredged materials $\left(3349 \pm 174 \mathrm{~kg} \mathrm{ha}^{-1}\right)$. The lowest forage yield of $1513 \pm 166 \mathrm{~kg} \mathrm{ha}^{-1}$ was from plots with $0 \%$ lakedredged materials. Mean forage yield of bahiagrass in plots with $50 \%$ lake-dredged materials of $2467 \pm 320 \mathrm{~kg} \mathrm{ha}^{-1}$ was not significantly different from that in plots with $75 \%$ lakedredged materials $\left(2467 \pm 320 \mathrm{~kg} \mathrm{ha}^{-1}\right)$ and $25 \%$ lake-dredged materials $\left(2409 \pm 423 \mathrm{~kg} \mathrm{ha}^{-1}\right)$, but was greater than that in plots with $0 \%$ lake-dredged materials (Fig. 6).

For Julian day 546 (78 weeks), mean forage yield of bahiagrass in plots with $100 \%$ lake-dredged materials of $3804 \pm$ $1120 \mathrm{~kg} \mathrm{ha}^{-1}$ was comparable with that of bahiagrass yield in plots with $75 \%$ lake-dredged materials $(4109 \pm 220 \mathrm{~kg}$ $\left.\mathrm{ha}^{-1}\right)$ and $50 \%$ lake-dredged materials $\left(3077 \pm 322 \mathrm{~kg} \mathrm{ha}^{-1}\right)$. However, mean forage yield of bahiagrass in plots with $75 \%$ lake-dredged materials was significantly higher than the mean forage yield of bahiagrass in plots with 50\%, 25\% (2780 \pm $\left.678 \mathrm{~kg} \mathrm{ha}^{-1}\right)$, and $0 \%\left(1263 \pm 116 \mathrm{~kg} \mathrm{ha}^{-1}\right)$ lake-dredged materials. Forage yield variability (83\%) of bahiagrass during its establishment can be explained by the addition of lake- dredged materials as shown by the equation below.

$$
\begin{aligned}
& \text { Forage yield }=25.64 \times \mathrm{LDM}+1724.3 \\
& \qquad R^{2}=0.83^{* * *} \quad P \leqslant 0.0001 .
\end{aligned}
$$

The greatest cumulative forage yield of bahiagrass of $7623 \pm$ $462.3 \mathrm{~kg} \mathrm{ha}^{-1}$ was from plots with $100 \%$ lake-dredged materials and the least cumulative forage yield of $2865 \pm 115 \mathrm{~kg} \mathrm{ha}^{-1}$ was from the control plots ( $0 \%$ lake-dredged material). $\mathrm{Cu}-$ mulative forage yield of bahiagrass from plots with $100 \%$ lake-dredged materials, 75\% lake-dredged materials, and 50\% lake-dredged materials did not vary among each other, but was significantly greater than the cumulative yield of bahiagrass grown in plots with $25 \%$ lake-dredged materials. Interestingly, cumulative yield of bahiagrass in plots with $25 \%$ lake-dredged materials was increased by $94 \%$ over the control plots while the average yield increase of bahiagrass (averaged across 50\% lake-dredged materials, $75 \%$ lake-dredged materials, and $100 \%$ lake-dredged materials) was about $145 \%$ over the untreated bahiagrass (Fig. 6).

\subsubsection{Effects on crude protein content}

The crude protein content of bahiagrass with and without lake-dredged materials during early establishment (Julian days 546) are shown in Figure 7. Results have shown the favorable influence that lake-dredged materials had on bahiagrass crude protein content. The crude protein content of bahiagrass varied significantly $(P \leqslant 0.001)$ with varying levels of lake-dredged materials applications. The tissues of bahiagrass with $100 \%$ lake-dredged materials had the highest crude protein $(151 \pm$ $22 \mathrm{~g} \mathrm{~kg}^{-1}$ ) and the lowest crude protein of $93 \pm 7 \mathrm{~g} \mathrm{~kg}^{-1}$ was 


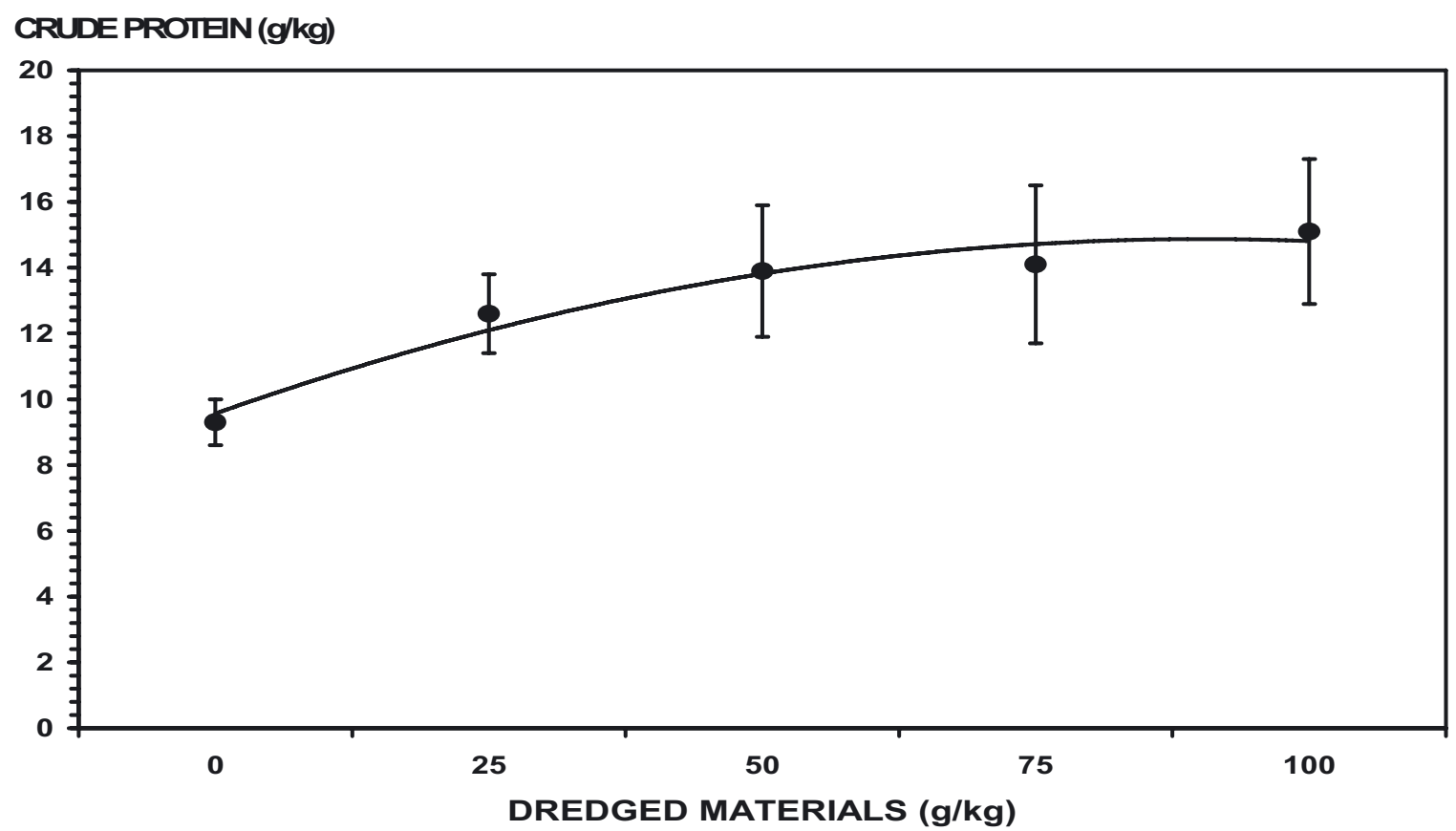

Figure 7. Relationships of crude protein content of bahiagrass with increasing rates of lake-dredged materials application. $\mathrm{y}=-0.4071 \mathrm{DM}{ }^{2}+$ $3.7529 \mathrm{DM}+6.22, \mathrm{R}^{2}=0.96 ; P \leq 0.0001$.

from the control plots ( $0 \%$ lake-dredged materials). The crude protein in plots with $50 \%\left(139 \pm 20 \mathrm{~g} \mathrm{~kg}^{-1}\right), 75 \%(141 \pm$ $\left.24 \mathrm{~g} \mathrm{~kg}^{-1}\right)$ and 100\% (151 $\left.\pm 22 \mathrm{~g} \mathrm{~kg}^{-1}\right)$ lake-dredged materials were statistically comparable, but were significantly different from the crude protein in the control plots (Fig. 7). However, the crude protein in the control plots was not different from the level of crude protein in plots with $25 \%$ lake-dredged materials. The crude protein of bahiagrass increased quadratically with increasing rates of lake-dredged materials application (Fig. 7). The crude protein response of bahiagrass to lakedredged materials application can be described by the equation below:

$$
\begin{array}{r}
\text { Crude protein }=-0.407 \times \mathrm{LDM}^{2}+3.7529 \times \mathrm{LDM}+6.22 \\
\qquad R^{2}=0.96^{* * *} \quad P \leqslant 0.0001 .
\end{array}
$$

\subsection{BIOSOLIDS}

All biosolids mostly used in research was of class B in terms of United States Environmental Protection Agency's pathogens and pollutant concentration limit (Tab. VII). Pathogen and chemical composition of the class B biosolids that were used in the study were all in compliance with the USEPA guidelines. Liquid sludge (SBS11) had the lowest fecal coliforms counts $\left(0.2 \times 10^{6} \mathrm{CFU} \mathrm{k^{-1 }}\right)$ while the cake biosolids (CBS) had the greatest coliforms counts of $178 \times 10^{6} \mathrm{CFU} \mathrm{kg}^{-1}$. The fecal coliforms counts for SBS7 were about $33 \times 10^{6} \mathrm{CFU} \mathrm{kg}^{-1}$. The fecal coliforms counts of all biosolids that were used in the study were below the USEPA fecal coliforms counts limit of $\leqslant 2000 \times 10^{6} \mathrm{CFU}$ $\mathrm{kg}^{-1}$ (Tab. VII). Concentrations of $\mathrm{As}, \mathrm{Cd}, \mathrm{Cu}, \mathrm{Pb}, \mathrm{Hg}, \mathrm{Mo}$,
$\mathrm{Ni}$, and $\mathrm{Zn}$ of biosolids again, were far below the national USEPA limits (Tab. VII). The total $\mathrm{P}$, total $\mathrm{N}$, and $\mathrm{K}$ contents of biosolids ranged from 22 to $33 \mathrm{~g} \mathrm{~kg}^{-1}, 39$ to $48 \mathrm{~g} \mathrm{~kg}^{-1}$, and 2.5 to $3.1 \mathrm{~g} \mathrm{~kg}^{-1}$, respectively. Based on their $\mathrm{N}$ and $\mathrm{P}$ compositions, biosolids can be used as low-grade nitrogen and phosphorus fertilizer and also as source of calcium especially the lime-stabilized residuals (Hue, 1995).

\subsubsection{Research highlights: cumulative and residual effects of repeated biosolids applications}

The objectives of this study were to evaluate the cumulative and residual effects of repeated applications of biosolids on (i) bahiagrass (Paspalum notatum Flügge) production over years with (1997-2000) and without (2001-2002) biosolids applications during a 5-yr period, and (ii) on nutrients status of soils that received annual application of biosolids from 1997 to 2000 compared with test values of soils in 2002 (with no biosolids application) in South Florida.

The field experiment was conducted at the University of Florida Agricultural Research and Education Center, Ona, FL $\left(27^{\circ} 26^{\prime} \mathrm{N}, 82^{\circ} 55^{\prime} \mathrm{W}\right)$ on a Pomona fine sandy soil. With the exception of the control, bahiagrass plots received annual biosolids and chemical fertilizers applications to supply 90 or $180 \mathrm{~kg}$ total $\mathrm{Nha}^{-1} \mathrm{yr}^{-1}$ from 1997 to 2000. Land application of biosolids and fertilizer ceased in 2001 season. In early April 1998, 1999, and 2000, plots were mowed to 5-cm stubble and treated with the respective $\mathrm{N}$ source amendments. The experimental design was three randomized complete blocks with nine N-source treatments: ammonium nitrate (AMN), slurry biosolids of pH 7 (SBS7), slurry biosolids of pH 11 (SBS11), 
Table VII. Some soil properties and average chemical and bacteriological composition of biosolids used for the experiment in relation to USEPA concentration limit.

\begin{tabular}{|c|c|c|c|c|c|}
\hline Parameter & Soils & Liquid sludge ( $\mathrm{pH} 7)$ & Liquid sludge (pH 11) & Cake biosolids & USEPA concentration limit \\
\hline Fecal coliforms CFU kg ${ }^{-1 \dagger}$ & & $33.3 \times 10^{6}$ & $0.15 \times 10^{6}$ & $177.5 \times 10^{6}$ & $\leqslant 2000 \times 10^{6}$ \\
\hline Total solids, $\mathrm{mg} \mathrm{L}^{-1}$ & & 47000 & 20500 & 500000 & \\
\hline Organic matter, $\mathrm{g} \mathrm{kg}^{-1}$ & 12 & & & & \\
\hline Total $\mathrm{P}, \mathrm{g} \mathrm{kg}^{-1}$ & 0.0014 & 25 & 22 & 33 & \\
\hline Total N, $\mathrm{g} \mathrm{kg}^{-1}$ & & 48 & 40 & 39 & \\
\hline Total $\mathrm{K}, \mathrm{g} \mathrm{kg}^{-1}$ & 0.0020 & 2.5 & 2.6 & 3.1 & \\
\hline As, $\mathrm{mg} \mathrm{kg}^{-1}$ & & 6.1 & 2.8 & 7.5 & 41 \\
\hline $\mathrm{Fe}, \mathrm{mg} \mathrm{kg}^{-1}$ & 18 & & & & \\
\hline $\mathrm{Cu}, \mathrm{mg} \mathrm{kg}^{-1}$ & 0.15 & 362 & 301 & 532 & 1500 \\
\hline $\mathrm{Cd}, \mathrm{mg} \mathrm{kg}^{-1}$ & & 2 & 10 & 4 & 39 \\
\hline $\mathrm{Cr}, \mathrm{mg} \mathrm{kg}^{-1}$ & & 6.5 & 34 & 48 & 1200 \\
\hline Mo, $\mathrm{mg} \mathrm{kg}^{-1}$ & & 7.7 & 8.0 & 10 & 18 \\
\hline
\end{tabular}

Colony forming units $\mathrm{kg}^{-1}$ of residuals.

$¥$ Concentration limits as defined in USEPA (1993).

lime-stabilized cake biosolids (CBS), each applied to supply 90 or $180 \mathrm{~kg} \mathrm{Nha}^{-1}$, and a nonfertilized control (Control). Application rates of biosolids were calculated based on the concentration of total solids in materials as determined by the American Public Health Association SM 2540G methods (APHA, 1989) and $\mathrm{N}$ in solids (see Sect. 1.1.2.2). The actual amount of biosolids applications was based on the amount required to supply 90 and $180 \mathrm{~kg} \mathrm{Nha}^{-1}$. Sewage sludge materials were weighed in buckets and uniformly applied to respective bahiagrass plots. Soil samples were collected in June 1997, June 1999, and in June 2002 from 27 treatment plots. In 1997 and 1999, soil samples were collected using a steel bucket type auger from the 0 - to 20-, 20- to 40-, 40- to 60-, and 60 - to $100-\mathrm{cm}$ soil depths.

Forage was harvested on 139, 203, 257, and 307 day of year (DOY) in 1998; 125, 202, 257, and 286 DOY in 1999; 179, 209, 270, and 301 DOY in 2000; and on 156 and 230 DOY in 2002 (no biosolids applications) to determine the residual effect of applied biosolids following repeated application. Forage yield and soils data were analyzed using analysis of variance procedures with year and treatment as the main plot and sub-plot, respectively (SAS, 2000). As a result of significant year effects on forage yield, data were reanalyzed annually (i.e., 1998, 1999, 2000, and 2002).

\subsubsection{Effects on forage yield}

Forage yield of bahiagrass was significantly $(P \leqslant 0.001)$ affected by the different biosolids in all years (1998 to 2002), but not by the interaction effects of year $\times$ treatments. Although yield trend was declining from 1988 to 2002, forage yield of bahiagrass that received biosolids were consistently and significantly $(P \leqslant 0.05)$ greater than the forage yield of the unfertilized bahiagrass (Tab. VIII). The bahiagrass fertilized with SBS11-180 had the greatest forage yield in 1998 $\left(5.1 \pm 0.4 \mathrm{Mgha}^{-1}\right), 1999\left(4.6 \pm 0.2 \mathrm{Mg} \mathrm{ha}^{-1}\right), 2000(4.5 \pm$ $\left.0.2 \mathrm{Mg} \mathrm{ha}^{-1}\right)$, and in $2002\left(3.3 \pm 0.6 \mathrm{Mg} \mathrm{ha}^{-1}\right)$. Forage yield of bahiagrass fertilized with AMN-90 and AMN-180 was significantly greater than those of the unfertilized bahiagrass in 1998 and 1999, but not in 2000 and in 2002. Although SBS11-180 had the greatest residual effect (170\%) in 2002, CBS-90 and CBS-180 had more pronounced effects when compared with the other sewage sludge sources because their relative impact on forage yield compared with the control between years with (1997-2000) and without (2002) sewage sludge applications increased from $30 \%$ to $110 \%$ and $70 \%$ to $110 \%$, or net increases of $267 \%$ and $57 \%$ in forage yield change, respectively (Fig. 8).

The residual effects of applied sewage sludge on bahiagrass yield expressed as percent forage yield change over the unfertilized bahiagrass are shown in Figure 8. Residual effects of AMN-90 (-6\%), AMN-180 (-31\%), SBS7-80 $(-21 \%)$, and SBS7-180 $(-17 \%)$ declined (negative) with time, but the residual effects of applied SBS11-180 (+13\%), CBS$90(+267 \%)$, and CBS-180 (+57\%) were positive over time although sewage sludge application ceased after harvest in 2000. The percent forage yield change of bahiagrass fertilized with SBS11-180, CBS-90, and CBS-180 during years when sewage sludges were applied (1998-2000) were 150\%, 30\%, and 70\% compared with percent forage yield change of $170 \%, 110 \%$, and $110 \%$ in 2002 (when sewage sludge applications ceased), respectively.

The residual effects on forage yield of applied CBS-90 $(+267 \%)$ and CBS-180 (+57\%) relative to the control increased with time although biosolids applications ceased after the 2000 harvest season (Fig. 8). This was probably due to the 
Table VIII. Comparison on forage yield $\left(\mathrm{Mg} \mathrm{ha}^{-1}\right.$; mean \pm S.D.) of bahiagrass among years with repeated application of biosolids (1998, 1999, and 2000) and with no biosolids application (2002).

\begin{tabular}{lcccc}
\hline Nitrogen & \multicolumn{3}{c}{ With sewage sludge } & Without sewage sludge \\
\cline { 2 - 4 } sources & 1998 & $1.8 \pm 0.2 \mathrm{c}$ & 2000 \\
\hline Control & $2.4 \pm 0.5 \mathrm{~d}$ & $3.7 \pm 0.1 \mathrm{~b}$ & $1.4 \pm 0.3 \mathrm{~d}$ & $1.2 \pm 0.2 \mathrm{c}$ \\
AMN-90 & $4.3 \pm 0.2 \mathrm{ab}$ & $4.7 \pm 0.02 \mathrm{a}$ & $2.1 \pm 0.1 \mathrm{~cd}$ & $2.1 \pm 0.3 \mathrm{bc}$ \\
AMN-180 & $4.7 \pm 0.4 \mathrm{a}$ & $3.1 \pm 0.3 \mathrm{~b}$ & $3.2 \pm 0.3 \mathrm{~b}$ & $2.2 \pm 0.4 \mathrm{~b}$ \\
SBS7-90 & $4.4 \pm 0.4 \mathrm{ab}$ & $5.1 \pm 0.2 \mathrm{a}$ & $2.2 \pm 0.4 \mathrm{bcd}$ & $2.5 \pm 0.5 \mathrm{ab}$ \\
SBS7-180 & $5.0 \pm 0.5 \mathrm{a}$ & $3.3 \pm 0.3 \mathrm{~b}$ & $2.6 \pm 0.2 \mathrm{bc}$ & $2.3 \pm 0.5 \mathrm{~b}$ \\
SBS11-90 & $4.1 \pm 0.5 \mathrm{abc}$ & $4.6 \pm 0.2 \mathrm{a}$ & $1.9 \pm 0.3 \mathrm{~cd}$ & $1.9 \pm 0.2 \mathrm{bc}$ \\
SBS11-180 & $5.1 \pm 0.4 \mathrm{a}$ & $2.2 \pm 0.2 \mathrm{c}$ & $3.3 \pm 0.6 \mathrm{a}$ \\
CBS-90 & $2.9 \pm 0.4 \mathrm{~cd}$ & $3.3 \pm 0.1 \mathrm{~b}$ & $1.8 \pm 0.6 \mathrm{~cd}$ & $2.5 \pm 0.5 \mathrm{ab}$ \\
CBS-180 & $3.3 \pm 0.3 \mathrm{bcd}$ & $2.7 \pm 0.2 \mathrm{bc}$ & $2.5 \pm 0.5 \mathrm{ab}$ \\
\hline
\end{tabular}

$\dagger$ Mean values in each column followed by the same letter(s) are not different $(P>0.05)$ according to the Duncan's multiple range test.

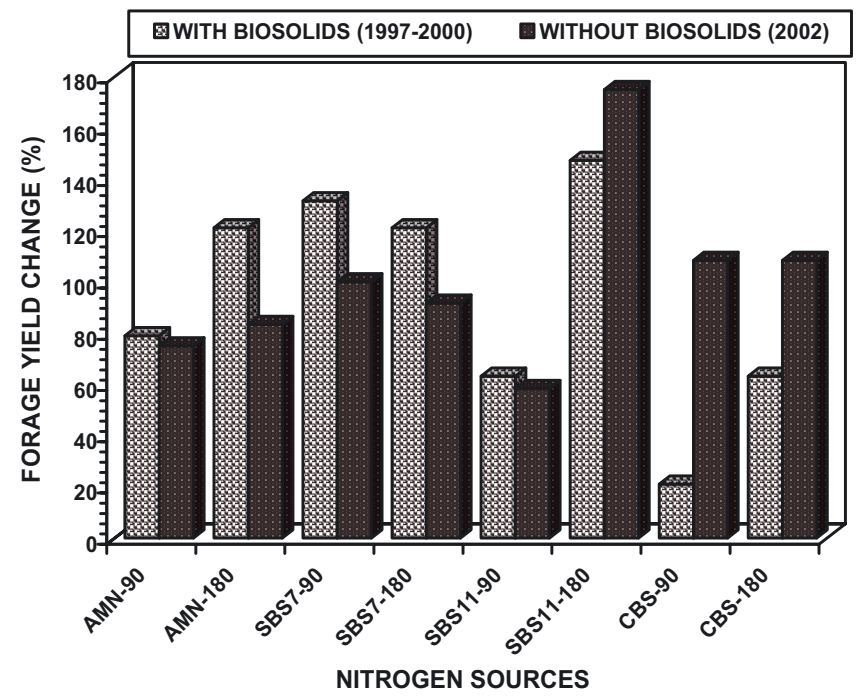

Figure 8. Residual effects of applied sewage sludge and ammonium nitrate fertilizer on forage yield change over the unfertilized bahiagrass with repeated sewage sludge application (1997-2000) and without sewage sludge application (2001-2002).

higher concentration of organic nitrogen in addition to the liming property of CBS. Liming the field could have some direct and indirect effects on forage productivity and on the nutrient status of the soils. Perhaps the single direct benefit of liming is the reduction in acidity and solubility of aluminum and manganese (Peevy et al., 1972). Some of the indirect benefits of liming pasture fields among others would include: enhancing $\mathrm{P}$ and microelement availability, nitrification, nitrogen fixation, and improving soil physical conditions (Nelson, 1980; Tisdale and Nelson, 1975; Russell, 1973). Dried and composted biosolids have slower rates of $\mathrm{N}$ release and in case of CBS with much higher solids concentration $\left(500000 \mathrm{mg} \mathrm{L}^{-1}\right)$; more $\mathrm{N}$ will be released in the second, third, or even the fifth year after the initial application due to higher amount of organic nitrogen than ammonium nitrogen. The proportions of ammonium and organic $\mathrm{N}$ in biosolids vary with the stabilization process.

Under an intensive management condition, bahiagrass maintained high forage yields through years with repeated biosolids applications and through years without biosolids application. Although the average bahiagrass forage yield in 2002 was slightly lower than in 2000, yield differences between the control and treated plots were indicative of a positive carry over effect of applied biosolids in 2002. Lime stabilized biosolids (SBS11, CBS) had the highest residual effects on bahiagrass forage yield and had enhanced overall soil characteristics. The carry over effect of these biosolids over the long term can be especially significant in many areas of Florida where only $50 \%$ of the 1 million ha of bahiagrass pastures are given inorganic nitrogen yearly. These biosolids if processed and applied according to USEPA rules (EPA, 1993) have the potential to boost and maintain production because they are inexpensive, environmentally safe, and could act as liming and organic matter amendment as well.

\subsubsection{Effects on soil chemical properties}

\subsubsection{Total inorganic nitrogen and total phosphorus}

Average soil test values in June 2002 exhibited: (i) decrease in total inorganic nitrogen $\left(\mathrm{NO}_{3}-\mathrm{N}+\mathrm{NH}_{4}-\mathrm{N}\right), \mathrm{TP}, \mathrm{K}, \mathrm{Ca}, \mathrm{Mg}$, $\mathrm{Al}, \mathrm{Mn}$, and Fe concentrations; and (ii) slight increase in $\mathrm{Zn}$ and $\mathrm{Cu}$ concentrations when compared with the June 1997 soil test results (Tab. IX). Levels of total inorganic nitrogen in June 1997, three months after initial biosolids applications, varied significantly with nitrogen sources, but total inorganic nitrogen concentrations leveled off in June 2002. As expected, plots with AMN (180 kg ha ${ }^{-1}$ ) had the greatest concentration of total inorganic nitrogen $\left(2.7 \mathrm{mg} \mathrm{kg}^{-1}\right)$ initially. Although the concentrations of total inorganic nitrogen in plots with different sources of nitrogen (DSS + AMN) were significantly higher than the concentrations of total inorganic nitrogen for the unfertilized plots in 1997, the concentrations of total inorganic nitrogen declined in 2002, suggesting no soil accumulations of nitrogen over time.

The concentrations of soil total phosphorus declined by almost $50 \%$ in plots with different nitrogen sources from June 1997 to June 2002 (Tab. IX). Plots with different sources of nitrogen had higher concentrations of total phosphorus than the unfertilized plots in June 1997 and in June 2002. However, 
Table IX. Comparative distribution of soil TP, K, Ca, Mg, Zn, Mn, Cu, Fe, Al, and Na with soil depth in June 1999 and in June 2002. (Source: Sigua et al., 2005.)

\begin{tabular}{lcccccccccccc}
\multicolumn{9}{c}{ A. June 1999 } \\
\hline Soil depth $(\mathrm{cm})$ & $\mathrm{TP}$ & $\mathrm{K}^{\ddagger}$ & $\mathrm{Ca}^{\ddagger}$ & $\mathrm{Mg}^{\ddagger}$ & $\mathrm{Zn}^{\ddagger}$ & $\mathrm{Mn}^{\ddagger}$ & $\mathrm{Cu}^{\ddagger}$ & $\mathrm{Fe}^{\ddagger}$ & $\mathrm{Al}^{\ddagger}$ & $\mathrm{Na}^{\ddagger}$ \\
\hline $0-20$ & $7.8 \mathrm{a}^{\ddagger}$ & $11.5 \mathrm{a}$ & $382.1 \mathrm{a}$ & $55.9 \mathrm{a}$ & $0.7 \mathrm{a}$ & $0.26 \mathrm{a}$ & $0.37 \mathrm{a}$ & $11.4 \mathrm{~b}$ & $58.1 \mathrm{a}$ & $10.6 \mathrm{a}$ \\
$20-40$ & $3.8 \mathrm{a}$ & $2.3 \mathrm{a}$ & $56.4 \mathrm{bc}$ & $12.5 \mathrm{c}$ & $0.3 \mathrm{~b}$ & $0.05 \mathrm{~b}$ & $0.05 \mathrm{~b}$ & $6.2 \mathrm{~b}$ & $30.4 \mathrm{a}$ & $5.7 \mathrm{~b}$ \\
$40-60$ & $6.7 \mathrm{a}$ & $6.4 \mathrm{a}$ & $93.1 \mathrm{~b}$ & $30.4 \mathrm{~b}$ & $0.4 \mathrm{~b}$ & $0.11 \mathrm{~b}$ & $0.03 \mathrm{~b}$ & $36.1 \mathrm{a}$ & $17.7 \mathrm{a}$ & $8.6 \mathrm{ab}$ \\
$60-100$ & $7.8 \mathrm{a}$ & $3.4 \mathrm{a}$ & $38.8 \mathrm{c}$ & $12.2 \mathrm{c}$ & $0.3 \mathrm{~b}$ & $0.05 \mathrm{~b}$ & $0.01 \mathrm{~b}$ & $14.3 \mathrm{~b}$ & $32.4 \mathrm{a}$ & $5.2 \mathrm{~b}$ \\
\hline
\end{tabular}

$\dagger$ Mean values in each column followed by the same letter(s) are not different $(P>0.05)$ according to the Duncan's multiple range test.

$\$ \mathrm{mg} \mathrm{kg}^{-1}$.

B. June 2002

\begin{tabular}{lccccccccccc}
\hline Soil depth $(\mathrm{cm})$ & $\mathrm{TP}$ & $\mathrm{K}^{\ddagger}$ & $\mathrm{Ca}^{\ddagger}$ & $\mathrm{Mg}^{\ddagger}$ & $\mathrm{Zn}^{\ddagger}$ & $\mathrm{Mn}^{\ddagger}$ & $\mathrm{Cu}^{\ddagger}$ & $\mathrm{Fe}^{\ddagger}$ & $\mathrm{Al}^{\ddagger}$ & $\mathrm{Na}^{\ddagger}$ \\
\hline $0-20$ & $5.4 \mathrm{a} \dagger$ & $2.0 \mathrm{a}$ & $56.6 \mathrm{a}$ & $8.7 \mathrm{a}$ & $0.5 \mathrm{a}$ & $0.11 \mathrm{~b}$ & $0.25 \mathrm{a}$ & $6.8 \mathrm{a}$ & $54.8 \mathrm{ab}$ & $14.9 \mathrm{a}$ \\
$20-40$ & $4.6 \mathrm{a}$ & $2.1 \mathrm{a}$ & $73.3 \mathrm{a}$ & $11.2 \mathrm{a}$ & $0.5 \mathrm{a}$ & $0.26 \mathrm{a}$ & $0.30 \mathrm{a}$ & $2.9 \mathrm{~b}$ & $34.7 \mathrm{~b}$ & $14.4 \mathrm{a}$ \\
$40-60$ & $3.1 \mathrm{a}$ & $0.9 \mathrm{~b}$ & $16.9 \mathrm{~b}$ & $3.4 \mathrm{~b}$ & $0.3 \mathrm{~b}$ & $0.03 \mathrm{~b}$ & $0.26 \mathrm{a}$ & $1.9 \mathrm{~b}$ & $89.9 \mathrm{a}$ & $14.4 \mathrm{a}$ \\
$60-100$ & $4.7 \mathrm{a}$ & $1.1 \mathrm{~b}$ & $15.4 \mathrm{~b}$ & $3.6 \mathrm{~b}$ & $0.4 \mathrm{ab}$ & $0.02 \mathrm{~b}$ & $0.29 \mathrm{a}$ & $4.5 \mathrm{ab}$ & $95.9 \mathrm{a}$ & $15.2 \mathrm{a}$ \\
\hline
\end{tabular}

$\dagger$ Mean values in each column followed by the same letter(s) are not different $(P>0.05)$ according to the Duncan's multiple range test.

$\neq \mathrm{mg} \mathrm{kg}^{-1}$.

the concentrations of total phosphorus in 2002 for plots with biosolids were not much higher than the concentrations of total phosphorus in the unfertilized plots. Again, application of biosolids did not result to any total phosphorus build up in the soil over time (1997-2002). Distribution of total phosphorus (averaged across treatments) also did not show significant build up with soil depth (Tab. IX). The levels of soil total phosphorus showed declining trend from June 1999 to June 2002. In June 2002, soil total phosphorus did not significantly vary with soil depth. The level of total phosphorus in the surface soil $(0-20 \mathrm{~cm})$ was about $5.4 \mathrm{mg} \mathrm{kg}^{-1}$ and $4.7 \mathrm{mg} \mathrm{kg}^{-1}$ at soil depth of 60-100 cm in June 2002. Likewise, soil test values of total phosphorus in June 1999 did not vary significantly with soil depth, i.e. $0-20 \mathrm{~cm}: 7.8 \mathrm{mg} \mathrm{kg}^{-1}$; 60-100 cm: $7.8 \mathrm{mg} \mathrm{kg}^{-1}$ (Tab. IX).

\subsubsection{2. $\mathrm{K}, \mathrm{Ca}$, and $\mathrm{Mg}$}

Similar to total phosphorus and total inorganic nitrogen, soil test values for $\mathrm{K}, \mathrm{Ca}$, and $\mathrm{Mg}$ declined significantly from June 1997 to June 2002 (Tab. IX). The concentrations of K, $\mathrm{Ca}$, and $\mathrm{Mg}$ in June 1997 ranged from 13.5 to $32.5,173.8$ to 287.7 , and 35.4 to $64.1 \mathrm{mg} \mathrm{kg}^{-1}$, respectively. Soil test values of $\mathrm{K}, \mathrm{Ca}$, and $\mathrm{Mg}$ in June 2002 ranged from 1.3 to 2.2, 22.8 to 53.9 , and 3.5 to $9.9 \mathrm{mg} \mathrm{kg}^{-1}$, respectively. Although the concentrations of soil $\mathrm{K}, \mathrm{Ca}$, and $\mathrm{Mg}$ (averaged across treatments) did decline over time, the surface soil $(0-20 \mathrm{~cm})$ had the greatest concentrations and tended to decrease with soil depth (Tab. IX). Again, biosolids application did not result to any build up of $\mathrm{K}, \mathrm{Ca}$, and $\mathrm{Mg}$ in the soils over time.

\subsubsection{3. $\mathrm{Zn}, \mathrm{Mn}$, and $\mathrm{Cu}$}

Slight increase in the concentrations of $\mathrm{Zn}$ and $\mathrm{Cu}$ were noted in June 2002 while the concentration of Mn tended to decrease from June 1997 to June 2002 (Tab. IX). The concentrations of $\mathrm{Zn}, \mathrm{Mn}$, and $\mathrm{Cu}$ (averaged across treatments) in June 1999 and in June 2002 did not vary much with soil depth, again with decreasing trends with soil depths, respectively. Concentrations of $\mathrm{Zn}$ and $\mathrm{Cu}$ in June 2002 did not change at all with soil depth (Tab. IX). The soil test values of $\mathrm{Mn}$ in 2002 decreased from $0.11 \mathrm{mg} \mathrm{kg}^{-1}$ at the soil surface $(0-20 \mathrm{~cm})$ to $0.02 \mathrm{mg} \mathrm{kg}^{-1}$ at soil depth of $60-100 \mathrm{~cm}$. The concentrations of $\mathrm{Zn}$ and $\mathrm{Cu}$ in plots with AMN-90, AMN180, CBS-90, CBS-180, and the unfertilized plots remained unchanged between June 1997 and June 2002, but slight increase in the concentrations of $\mathrm{Zn}$ and $\mathrm{Cu}$ were observed from plots with SBS7-90, SBS7-180, SBS11-90, and SBS11-180. The concentrations of Mn across treatments showed a general decline in June 2002, but their concentrations were not significantly different from the control (Tab. IX).

\subsubsection{Al, Fe, and $\mathrm{Na}$}

The concentrations of $\mathrm{Al}$ across treatments tended to decline significantly from June 1997 to June 2002 while the concentrations of $\mathrm{Fe}$ and $\mathrm{Na}$ remained unchanged from June 1997 to June 2002 (Tab. IX). In June 2002, the concentrations of $\mathrm{Al}$ across treatments declined by about $88 \%$ (274 to $32 \mathrm{mg} \mathrm{kg}^{-1}$ ). The concentrations of $\mathrm{Fe}$ and $\mathrm{Na}$ in June 1997 ranged 4.8 to $15.2 \mathrm{mg} \mathrm{kg}^{-1}$ and 6.2 to $11.1 \mathrm{mg} \mathrm{kg}^{-1}$ compared with their concentrations of 1.7 to $9.7 \mathrm{mg} \mathrm{kg}^{-1}$ and 13.5 to 15.5 $2.1 \mathrm{mg} \mathrm{kg}^{-1}$ in June 2002, respectively (Tab. IX). The concentrations of Fe and Al (averaged across treatments) in June 1999 did not vary with soil depth. The level of $\mathrm{Na}$ decreased from $10.6 \mathrm{mg} \mathrm{kg}^{-1}(0-20 \mathrm{~cm})$ to $5.2 \mathrm{mg} \mathrm{kg}^{-1}(60-100 \mathrm{~cm})$. In June 2002, the concentrations of $\mathrm{Fe}$ and $\mathrm{Al}$ (averaged across treatments) at 0-20 cm were comparable with their concentrations at $60-100 \mathrm{~cm}$, suggesting no build up of Fe and Al within soil profile The concentrations of $\mathrm{Na}$ in June 2002 likewise did not vary with soil depth (Tab. IX).

All sources of $\mathrm{N}$ (domestic biosolids and AMN) gave better forage production than the unfertilized control during years with domestic biosolids application (1997-2000) and also 
during years with no domestic biosolids application (20012002). Although the average bahiagrass forage yield in 2002 $\left(2.3 \pm 0.7 \mathrm{Mg} \mathrm{ha}^{-1}\right)$ was slightly lower than in $2000(3.5 \pm$ $1.2 \mathrm{Mgha}^{-1}$ ), yield differences in 2002 between the control $\left(1.2 \pm 0.2 \mathrm{Mg} \mathrm{ha}^{-1}\right)$ and treated plots $\left(2.3 \pm 0.5 \mathrm{Mg} \mathrm{ha}^{-1}\right.$ to $3.3 \pm 0.6 \mathrm{Mg} \mathrm{ha}^{-1}$ ) were indicative of a positive carry over effect of applied domestic biosolids. The favorable carry over or residual effects of applied domestic biosolids in 2002 may have had received additional boost from the amount of rainfall in the area. Rainfall varied between years, which caused the initial forage harvest in 1998 and forage harvest in 2002 to differ. It should be noted that applications of domestic biosolids and AMN fertilizers ceased after the 2000 harvest season. The total annual rainfall in the area was $1735,1253,801,1643$, and $1756 \mathrm{~mm}$ in 1998, 1999, 2000, 2001, and 2002, respectively. Additionally, domestic biosolids (especially the SBS and CBS) supported forage production at a similar rate and to the same extent as the inorganic AMN fertilizers during the first three years (1997-2000) of repeated land application and during the succeeding years with no domestic biosolids (2000 2001) application.

The residual effects on forage yield of applied CBS-90 $(+267 \%)$ and CBS-180 $(+57 \%)$ relative to the control increased with time although domestic biosolids applications ceased after the 2000 harvest season (Fig. 8). This was probably due to the higher concentration of organic nitrogen in addition to the liming property of CBS. Liming the field could have some direct and indirect effects on forage productivity and on the nutrient status of the soils. Perhaps the single direct benefit of liming is the reduction in acidity and solubility of aluminum and manganese (Peevy et al., 1972). Some of the indirect benefits of liming pasture fields among others would include: enhancing P and microelement availability, nitrification, nitrogen fixation, and improving soil physical conditions (Nelson, 1980; Tisdale and Nelson, 1975; Russell, 1973).

Dried and composted domestic biosolids have slower rates of $\mathrm{N}$ release and in case of CBS with much higher solids concentration $\left(500000 \mathrm{mg} \mathrm{L}^{-1}\right)$; more $\mathrm{N}$ will be released in the second, third, or even the fifth year after the initial application due to higher amount of organic nitrogen than ammonium nitrogen. The proportions of ammonium and organic $\mathrm{N}$ in domestic biosolids vary with the stabilization process. The limestabilized and anaerobically digested CBS would normally contain 25\% ammonium nitrogen and $75 \%$ organic nitrogen (Evanylo, 1999). Organic nitrogen must be broken down initially to $\mathrm{NH}_{4}^{+}$and $\mathrm{NO}_{3}^{-}$by soil microorganisms before this form of nitrogen becomes available for plant use; therefore, organic nitrogen can be considered to be a slow release form of nitrogen. The organic nitrogen not mineralized during the first year (1997) after application of our study is mineralized slowly in succeeding years even domestic biosolids applications ceased in 2001 season. Since CBS was applied annually (equivalent to 90 and $180 \mathrm{~kg} \mathrm{~N} \mathrm{ha}^{-1}$ ) on the same site that began in 1997 and ceased in 2000, mineralization of organic nitrogen may still be occurring even after the 2000 harvest season. Because of the slow mineralization process from CBS with higher organic nitrogen fully supported our results (i.e. residual effects of applied CBS-90 of $+267 \%$ and CBS- 180 of $+57 \%$ relative to the control). Additionally, CBS may have had provided essential micronutrients including copper, boron, molybdenum, zinc, and iron to bahiagrass. Of these micronutrients, molybdenum and iron are playing vital roles during plant's photosynthetic activities.

Repeated applications of domestic biosolids indicate no harmful environmental or plant effects. Results support the hypothesis that repeated land application of domestic biosolids to supply 90 and $180 \mathrm{~kg} \mathrm{Nha}^{-1}$ would not increase soil sorption for P, trace, and heavy metals. Results have indicated that the concentrations of soil TIN and TP declined by almost 50\% in plots with different nitrogen sources from June 1997 to June 2002 suggesting that enrichment, mobility, or leaching of nitrogen and phosphorus to ground water is insignificant. The concentrations of soil nitrogen and phosphorus in 2002 following repeated application of domestic biosolids were far below the contamination risk in the environment (EPA, 1993). Sewage sludge contains both organic and inorganic forms of nitrogen and phosphorus. After land application, the residualderived nitrogen and phosphorus enter the soil nitrogen and phosphorus cycle, respectively (Basta, 1997; Stevenson, 1986, 1982). Mineralization of organic phosphorus will convert it to plant-available dissolved phosphate and shortly after release as dissolved phosphate; soil chemical adsorption and precipitation processes decreased dissolved phosphorus to a low concentration in soil solution. The rate of nutrient release, or mineralization, is affected by the stabilization process used to treat domestic wastewaters. Amounts of nitrogen mineralized under laboratory conditions depend heavily on the domestic biosolids treatment process and ranged from 10 to $40 \%$ (Gilmour et al., 2003, 1985; EPA, 1983) while mineralization rates under field conditions are more variable and ranged from seven to $55 \%$ of the organic nitrogen mineralized (Gilmour et al., 2003; Evanylo, 1999; Basta, 1997; Gilmour and Clark, 1988).

The levels of trace metals in the soils after repeated applications of biosolids did not indicate $\mathrm{Mn}, \mathrm{Al}$, and $\mathrm{Fe}$ enrichment in the soils (Tab. IX). Previous work of Chang et al. (1987) collaborated with previous research results. Chang et al. (1987) reported that the mobility of metals is greatest in the first year and decreases with time which is in direct contradiction to the "time bomb effect" suggested by Beckett and Davis (1979). Beckett and Davis (1979) claimed that decomposition of residuals would release metals that would eventually result in metal toxicity (especially heavy metals) in the soil. Research results presented in this paper do not support the "time bomb" theory, but likely supporting the concepts postulated by Chaney (1973), where soil chemical process reduce heavy metals availability in residuals-amended soils with time. These heavy metals may occur in residuals as insoluble precipitates, surface adsorbed mineral complexes, and insoluble organic matter chelates (Corey et al., 1987). The concentrations of $\mathrm{Cu}$ and $\mathrm{Zn}$ reported for June 2002 in soils with SBS7-180, SBS11-180, and CBS-90 were slightly elevated, but not toxics. The concentrations of $\mathrm{Cu}$ and $\mathrm{Zn}$ in 2002 were still within the norms for sludge heavy metals (Tab. IX) as reported by the US Environmental Protection Agency (EPA, 1993). 


\section{SUMMARY AND CONCLUSIONS}

Land application of lake-dredged materials and biosolids may provide substantial benefits that will enhance the environment, community, and society. The trace metal contents of these materials were below the threshold effect levels. As such, the agricultural or livestock industry could utilize these materials to produce forages. Although results have demonstrated the promising effects of added lake-dredged materials and biosolids on the early establishment of bahiagrass in pasture fields, further studies are still needed not only in pastures of south Florida, but also in other areas of the world with similar climatic conditions to determine whether the environmental and ecological implications of these materials are satisfied or not either in shorter or longer term.

The ability to reuse lake-dredged and domestic sewage sludge materials for agricultural purposes is important because it reduces the need for offshore disposal and provides an alternative to disposal of these materials in landfills that are already overtaxed. Often these materials can be obtained at little or no cost to the farmers or landowners. Thus, forage production offers an alternative to waste management since nutrients in the lake-dredged materials and biosolids are recycled into crops that are not directly consumed by humans. Results have shown the favorable influence that biosolids and lake-dredged materials had on bahiagrass during its early establishment in sandy subtropical beef cattle pasture areas in south central Florida. Some of the promising effects of added biosolids and lakedredged materials on soil quality and on early establishment of bahiagrass are summarized below.

- Favorable influence that lake-dredged materials had on soil penetrometer resistance. Higher rate of application may have had improved structure and tilth of sandy soils, which can promote water holding capacity, sufficient aeration and creates more friable soils. This is largely the result of an increase in the organic matter content and to a lesser extent to the flocculation of calcium-saturated colloids.

- The lake-dredged materials have provided the benefits that we normally would obtain from liming the field using commercially available lime. Compared with the control plots, the soils in plots amended with lake-dredged materials exhibited an increase in soil $\mathrm{pH}$, total inorganic nitrogen, calcium, and magnesium.

- Forage yield $\left(\mathrm{Mg} \mathrm{ha}^{-1}\right)$ variability $(83 \%)$ of bahiagrass during its establishment can be explained by the addition of lake-dredged materials as shown by this equation (forage yield $=25.64 \times \mathrm{LDM}+1724.3$ ) .

- The crude protein of bahiagrass increased quadratically with increasing rates of lake-dredged materials application. The crude protein response of bahiagrass to lakedredged materials application can be described by this equation (crude protein $=-0.407 \times \mathrm{LDM}^{2}+3.7529 \times$ $\mathrm{LDM}+6.22$ ).

- Forage yield of bahiagrass was significantly affected by the different sewage sludges in all years (1997 to 2002). Forage yield of bahiagrass that received biosolids were consistently and significantly greater than the forage yield of the unfertilized bahiagrass. Although the average forage yield of bahiagrass in $2002\left(2.3 \pm 0.7 \mathrm{Mgha}^{-1}\right)$ was slightly lower than in $2000\left(3.5 \pm 1.2 \mathrm{Mg} \mathrm{ha}^{-1}\right)$, yield differences in 2002 between the control $\left(1.2 \pm 0.2 \mathrm{Mg} \mathrm{ha}^{-1}\right)$ and treated plots $\left(2.3 \pm 0.7\right.$ to $\left.3.3 \pm 0.6 \mathrm{Mg} \mathrm{ha}^{-1}\right)$ were indicative of a positive carry over effect of applied biosolids.

- Repeated applications of sewage sludge indicate no harmful environmental or plant effects. Excessive build up of plant nutrients (e.g. total $\mathrm{N}$, total $\mathrm{P}$, and trace metals) as expected did not occur in beef cattle pastures that repeatedly received sewage sludge materials while favoring long-term increased forage yield of bahiagrass.

- Biosolids if processed and applied according to the USEPA rules have the potential to boost and maintain production because they are inexpensive, environmentally safe, and could act as liming and organic matter amendment as well.

- Successive land application of biosolids for at least three years followed by no sewage sludge application for at least two years would be a good practice economically and environmentally because it will boost and/or maintain sustainable forage productivity and at the same time minimize probable accumulation of nutrients, especially heavy metals.

\section{RESEARCH DIRECTION AND OUTLOOK}

Forage production offers an alternative to waste management since nutrients in the waste are recycled into crops that are not directly consumed by humans. Establishment of an excellent, uniform stand of bahiagrass in a little time period is essential and economical. Failure to obtain an early good stand means the loss of not only the initial investment costs, but production and its cash value. Forage production often requires significant inputs of lime, nitrogen fertilizer, and less frequently of phosphorus and potassium fertilizers. Bahiagrass is a good general-use pasture grass that can tolerate a wide range of soil conditions and close grazing, and withstands low fertilizer input (Burson and Watson, 1995; Kidder, 2001, 1995; Kincheloe et al., 1987). It has the ability to produce moderate yields on soils of very low fertility and easier to manage than other improved pasture grasses (Chambliss, 1999).

Land application of biosolids for at least three (3) years followed by no biosolids application for at least two (2) years may be a good practice economically and environmentally because it will enhance and/or maintain sustainable forage productivity and at the same time minimize probable accumulation of nutrients to a certain degree, especially heavy metals. However, in the longer term, consecutive applications of biosolids may result in build up of toxic metals in soils. The possibilities for environmentally and economically sound application strategies are encouraging, but more and additional research is required to find most favorable timing and rates that minimizes negative impacts on the environment. For proper utilization of biosolids, knowledge of the biosolids composition and the crop receiving it are crucial, so that satisfactory types and rates are applied in an environmentally safe manner. 
Land application of lake-dredged materials and biosolids may not only provide substantial benefits that will enhance the environment, community, and society in south Florida, but also in other parts of the world especially those areas having tropical and subtropical climate with forage-based beef cattle pastures. As such, the agricultural or livestock industry could utilize biosolids and lake-dredged materials to produce forages. Lake-dredge materials and biosolids should be regarded as valuable resources, as part of the ecological system.

Is the use of biosolids and lake-dredged materials in an agricultural setting protected and realistic? Is the use of these materials safe and sound in all climates, in all soils and is it sustainable over the long term? Since the benefits of forages in cropping system are sometimes understated and do not manifest themselves immediately, the use of biosolids and lakedredged materials as alternative sources of nutrients in foragebased pastures research needs should be conducted over the longer term. Perhaps, the greatest research needs is to maintain long-term, field-based forage research programs, and establish new programs that address new questions.

There is still much to be learned whether the environmental and ecological objectives are satisfied over the longer term. Additional research on disposal options of lake-dredged materials and biosolids are much needed to supply information on criteria testing and evaluation of the physical and chemical impacts of biosolids and lake-dredged materials at disposal sites. The first necessary step in evaluating the sludge and lake-dredged materials application alternatives is to determine whether these materials are suitable for use on agricultural land. Therefore, the biosolids and lake-dredged materials should be analyzed carefully and thoroughly to evaluate their quality. The parameters most commonly measured would include percentage total solids, total nitrogen, ammonium and nitrate nitrogen, total $\mathrm{P}$ and $\mathrm{K}$ and total cadmium, copper, nickel, lead, and zinc, chromium and mercury.

Despite of the relative success of recycling biosolids and lake-dredged materials as reported in this paper, one of essential areas of future research would be on the effect of recycling of biosolids and lake-dredged materials on the costeffective performance of pasture-based agriculture, and the market awareness of animal products produced from land receiving biosolids and lake-dredged materials.

\section{REFERENCES}

Adams E., Pederson J. (2001) Dredged materials management background information, MIT Dredged Material Management Conference, Abstract, Massachusetts, USA.

Adjei M.B., Rechcigl. J.E. (2002) Bahiagrass production and nutritive value as affected by domestic wastewater residuals, Agron. J. 94, $1400-1410$

Alloway B.J., Jackson A.P. (1991) The behavior of heavy metals in sewage-sludge amended soils, Sci. Total Environ. 100, 151-176.

American Public Health Association (1989) Total, fixed, and volatile solids and semisolid samples (SM 2540), in: Clesceri S. et al. (Eds.), Standard methods for the examination of water and wastewater, AM, Public Health Assoc., Washington, DC, pp. 2-78; p. 2-79.
Basta N.T. (1997) Transformations of land-applied residuals, in: Kugler A.M. (Ed.), Biosolids management in Florida. Beneficial use of domestic wastewater residuals, Gainesville, FL, 58, pp. 17-21.

Beckett P.H.T., Davis R.D. (1979) The disposal of biosolids onto farmland: the scope of the problem of toxic elements, Water Pollut. Contr. 78, 419-445.

Berti W.R., Jacobs L. (1996) Chemistry and phytotoxicity of soil trace elements from repeated biosolids applications, J. Environ. Qual. 25, $1025-1032$.

Botcher A.B., Tremwel T.K., Campbell K.L. (1999) Phosphorus management in flatwood (Spodosols) soils, in: Reddy K.R. et al. (Eds.), Phosphorus Biogeochemistry in Subtropical Ecosystems, Lewis Publishers, Boca Raton, FL, pp. 405-423.

Burson B.L., Watson V.H. (1995) Bahiagrass, dallisgrass, and other paspalum species, in: Barnes R.F., Miller D.A., Nelson C.J. (Eds.), Forages, Vol. 1, Iowa State Univ. Press Iowa, pp. 431-440.

Cavallaro N., Padilla N., Villarrubia J. (1993) Sewage sludge effects on chemical properties of acid soils, Soil Sci. 156, 63-70.

Chambliss C.G. (1999) Florida Forage Handbook, University Florida Coop. Ext. Serv. SP253, University of Florida, Gainesville, FL, p. 142.

Chaney R.L. (1973) Crop and food chain effects of toxic elements in sludge and effluents, in: Recycling municipal sludges and effluents on land, Nat. Assoc. St. Univ. and Land Grant Coll, Washington DC, pp. 129-141.

Chang A.C., Hinsely T.D., Bates T.E., Doner H.E., Dowdy R.H., Ryan J.A. (1987) Effects of long-term sludge application on accumulation of trace elements by crops, in: Page A.L., Logan T.J., Ryan J.A. (Eds.), Land application of sludge: food chain implications, Lewis Publisher, Chelsea, MI, pp. 53-66.

Cogger C.G., Bary A.L., Fransen S.C., Sullivan D.M. (2001) Seven years of biosolids vs. inorganic nitrogen applications to tall fescue, J. Environ. Qual. 30, 2188-2194.

Cogger C.G., Sullivan D.M., Bary A.L., Fransen S.C. (1999) Nitrogen recovery from heat-dried and dewatered biosolids applied to forage grasses, J. Environ. Qual. 28, 754-759.

Corey R.B., King L.D., Fanning D.S., Street J.J., Walker J.M. (1987) Effects of sludge properties on accumulation of trace elements by crops, in: Page A.L., Logan T.J., Ryan J.A. (Eds.), Land application of sludge: food chain implications, Lewis Publisher, Chelsea, MI.

Environmental Protection Agency (1983) Process design manual for sludge treatment and disposal, Municipal Environmental Research Laboratory, Cincinnati, OH, EPA/625/1-83-016.

Environmental Protection Agency (1993) Standards for the use and disposal of biosolids, 40 CFR Parts 257, 402 and 502, FRL-4203-3, Washington DC.

Evanylo G.K. (1999) Agricultural land application of biosolids in Virginia: managing biosolids for agricultural use, VA Cooperative Extension, Publication Number 452-303, p. 10.

Fitzgerald S., Pederson J. (2001) Use of geographic information systems to aid in siting dredged material disposal areas, MIT Dredged Material Management Conference, Abstract, Massachusetts, USA.

Follet R.F., Wilkinson S.R. (1995) Nutrient management of forages, in: Barnes R.F. et al. (Eds.), Forages, The Science of Grassland Agriculture, Iowa State University Press, Ames, IA, pp. 55-82.

Fresquez P.R., Francis R.E., Dennis G.L. (1990) Sewage sludge effects on soil and plant quality in a degraded, semiarid grasslands.

Gambrel R.P., Khalid R.A., Patrick W.H. Jr. (1978) Disposal alternatives for contaminated dredged material as a management tool to minimize adverse environmental effects, Technical Report DS-788, Corp, Engineers, Washington, DC, p. 148.

Gilmour J.T., Clark M.D. (1988) Nitrogen release from wastewater sludge: A site specific approach, J. Water Pollut. Control Fed. 60, 494-498. 
Gilmour J.T., Clark M.D., Sigua G.C. (1985) Estimating net nitrogen mineralization from carbon dioxide evolution, Soil Sci. Soc. Am. J. 49, 1398-1402.

Gilmour J.T., Cogger C.G., Jacobs L.W., Evanylo G.K., Sullivan D.M. (2003) Decomposition and plant-available nitrogen in biosolids: laboratory studies, field studies, and computer simulation, J. Environ. Qual. 32, 1498-1507.

Henry C.L., Cole D.W., Harrison R.B. (1994) Use of municipal sludge to restore and improve site productivity in forestry: the Pack Forest Sludge Research Program, Forest Ecol. Manag. 66, 137-149.

Hue N.V. (1995) Sewage sludge, in: Rechcigl J.E. (Ed.), Soil amendments and environmental quality, Lewis Publishers, Boca Raton, FL, p. 504, pp. 199-247.

Johnson J., Eckert D. (1995) Best management practices: land application of animal manure, The Ohio State University Extension Agronomy Facts, AGF-208-95, Columbus, OH, 10 p.

Kidder G. (1995) Applying non-hazardous wastes to land: III. Land application of biosolids, FL, Coop. Ext. Serv. Notes in Soil and Water Sci, SS-SOS-45, University of Florida, Gainesville.

Kidder G. (2001) Using waste products in forage production, in: Chamblis C.G. (Ed.), Florida Forage Handbook, University of Florida, Gainesville, FL, p. 142, pp. 88-93.

Kincheloe S., Houm R.A., Reed F.J., Bergeau P.J., Morris H.D., Reetz H.F., Case V.W., Sevey M.E. (1987) Efficient fertilizer use, Int. Minerals and Chem. Corp., Mundelein, IL.

King L.D., Taylor R.W., Shuford J.W. (1986) Macronutrients in municipal and industrial sludges and crop response to sludge application, in: King L.D. (Ed.), Agricultural use of municipal and industrial sludges in the southern United States, South. Coop. Ser. Bull. 314, North Carolina State Univ., Raleigh.

Krause P.R., McDonnell K.A. (2000) The beneficial reuse of dredged material for upland disposal, Harding Lawson Associates, Novato, CA, p. 23.

MacDonald D.D. (1994) Approach to the assessment of sediment quality in Florida coastal waters, FDEP, Tallahassee, FL, p. 140.

Mehlich A. (1953) Determination of $\mathrm{P}, \mathrm{Ca}, \mathrm{Mg}, \mathrm{K}, \mathrm{Na}$, and $\mathrm{NH}_{4}$, North Carolina Soil Test Division, Mimeo, Raleigh, NC.

Muchovej R.M., Obreza T.A. (2001) Biosolids: are these residuals all the same? IFAS, University of Florida, Gainesville, FL, p. 4.

Murdock L., Gray T., Higgins F., Wells K. (1995) Soil compaction in Kentucky, Cooperative Extension Service, Univ. Kentucky, Lexington, AGR-161Muse, J.K.C.C.

Muse J.K., Mitchell C.C., Mullins G.L. (1991). Land application of sludge, Ala. Coop. Ext. Serv. Circ. ANR-607, Auburn University, Auburn, AL.

National Dredging Team (2003) Dredged material management: Action agenda for the next decade, EPA, Jacksonville, FL, p. 87.

Nelson W.L. (1980) Agricultural liming: its effect on soil fertility, plant nutrition, and yields, in: Proc. 1st Natl. Conf. Agric. Limestone, Nashville, TN, pp. 34-39.

Obreza T.A., O'Connor G. (2003) The basics of biosolids application to land in Florida, Fl Coop. Ext. Serv. SL-205, IFAS, University of Florida, Gainesville, FL, p. 4.

Patel S.K., Steward J.S., Erickson W.A., Sigua G.C. (2001) Restoration dredging and beneficial uses of sediments: a management perspective on the Indian River Lagoon, Florida, in: Randall R.E. (Ed.), Proceedings of the western dredging association twenty-first technical conference, Houston, TX, pp. 109-118.

Pearson R.W., Hoveland C.S. (1974) Lime needs of forage crops, in: Mays D.A. (Ed.), Forage fertilization, Madison, Wis. ASA-CSSASSSA, pp. 301-322.

Peevy W.J., Brupbacher R.H., Sedberry J.E. Jr. (1972) Effects of some liming materials and calcium sulfate on soil reaction and exchange- able calcium and magnesium, LSU Agr. Center, Baton Rouge, LA, p. 8.

Russell W.E. (1973) Soil conditions and plant growth, William Clowes \& Sons, Limited, London, p. 849.

Sharpley A.N., Daniel T.C., Sims J.T., Pote D.H. (1996) Determining environmentally sound soil phosphorus levels, J. Soil Water Conserv. $51,160-166$.

Sigua G.C. (2005) Current and future outlook of spoil and sludge materials in agriculture and environment, J. Soils Sediments 5, 50-52.

Sigua G.C., Adjei M.B., Rechcigl J.E. (2005) Cumulative and residual effects of repeated biosolids applications: forage productivity and soil quality implications in South Florida, USA, Environ. Sci. Pollut. R. $12,80-88$.

Sigua G.C., Coleman S.W., Holtkamp M.L. (2006) Land application of carbonatic lake-dredged materials: effects on soil quality and forage productivity, J. Environ. Qual. 35, 1784-1794.

Sigua G.C., Holtkamp M.L., Coleman S.W. (2004a) Assessing the efficacy of lake-dredged materials from Lake Panasoffkee, Florida: Implication to environment and agriculture. Part 1 - Soil and Environmental Quality Aspect, ESPR - Environ. Sci. Pollut. Res. $11,321-326$.

Sigua G.C., Holtkamp M.L., Coleman S.W. (2004b) Assessing the efficacy of lake-dredged materials from Lake Panasoffkee, Florida: Implication to environment and agriculture, Part 2 - Pasture Establishment and Forage Quality, ESPR - Environ. Sci. Pollut. Res. 11, 394-399.

Sigua G.C., Holtkamp M.L., Linton J.M., Coleman S.W. (2003) Land application of lake-Lake-dredged materials for bahiagrass establishment in subtropical beef pasture, J. Soils Sediments 3, 93-99.

Smith L. (1997) Regulations affecting the beneficial use of residuals, Florida Dept. of Environmental Protection, Tallahassee, FL, p. 6.

Speir T.W., van Schaik A.P., Percival H.J., Close M.E., Pang. L. (2003), Heavy metals in soil, plants and groundwater following high rate of sewage sludge application to land, Water Air Soil Poll. 150, 319358.

Statistical Analysis System (SAS) (2000) SAS/STAT User's Guide, Release 6.03, SAS Institute, Cary, North Carolina, p. 494.

Stevenson F.J. (1982) Origin and distribution of nitrogen in soil, in: Stevenson F.J. (Ed.), Nitrogen in agricultural soils, Agron. Monogr. 22, ASA, CSSA and SSSA, Madison WI, pp. 155-215.

Stevenson F.J. (1986) The internal cycle of nitrogen in soil, in: Cycles of soil: carbon, nitrogen, phosphorus, sulfur, and micronutrients, John Wiley \& Sons, New York, pp. 155-182.

Sullivan D.M. (1998) Fertilizing with biosolids, Washington State University Coop. Ext. Serv. PNW 508, p. 11.

Sullivan D.M., Fransen S.C., Cogger C.G., Bary A.I. (1997) Biosolids and dairy manure as nitrogen sources for prairie grass on poorlydrained soils, J. Prod. Agric. 10, 589-596.

Thomas W. (1996) Soil pH and Soil Acidity, in: Sparks D.L. et al. (Eds.), Methods of Soil Analysis, Part 3, Chemical Method, SSSA Book Series No. 5, Soil Science Society of America, Madison, WI, pp. 475-491.

Tisdale S.L., Nelson W.L. (1975) Soil fertility and fertilizers, Macmillan Publishing Co., Inc, New York, p. 694.

Walkley A., Black I.A. (1934) An examination of Degtjareff method for determining soil organic matter and a proposed modification of the chromic acid titration method, Soil Sci. 37, 29-38.

Wenning R., Woltering D. (2001) Use of ecological risk assessment methods to evaluate dredged material management options, MIT Dredged Material Management Conference, Abstract.

Zebarth B.J., McDougall R., Nielsen G., Nielsen D. (2000) Availability of nitrogen from municipal biosolids for dry land forage grass, Can J. Plant Sci. 80, 575-582. 